\title{
The Byzantine Imperial Chancery and its Language Policy from Justin II to Leo III (Sixth-Eighth Centuries): From Latin to Greek
}

\section{Christian Gastgeber*}

This article traces the development of language use in the imperial chancery of Constantinople. After Emperor Justinian I permitted Greek as the official language for documents concerning the Greek-speaking areas, his successors followed this path; Greek was increasingly preferred and started to replace Latin in documents that addressed the entire empire and, in a final stage, in imperial documents directed to Western addressees. To illustrate this process, the respective documents are discussed insofar as the preserved texts allow the drawing of safe conclusions about their original language and the stages of its development. For this reason, the texts are examined with regard to the target audience and, if Latin, to chancery or local translations.

Keywords: Byzantine chancery; Latin in Byzantium; Byzantine documents; Byzantine laws; Latin documents in Byzantium

\section{Introduction}

From a broader perspective, the documents of the Byzantine imperial chancery are an illuminating source with regard to socio-political opportunities. Their shape and text presentation provide further insight into the respective status and policy of the Byzantine emperors. This study will examine one of these parameters: the choice of language for imperial documents in the early Byzantine period. ${ }^{1}$ Admittedly, it is a first attempt at studying the language policy in early Byzantine chancery products from this point of view. It is a well-known fact that Latin terms, mainly those from the field of law but also in connection with administration, were gradually replaced by Greek equivalents (in two stages: first the Latin words were written with Greek letters, then the terms were replaced by Greek equivalents), a process that is termed "exhellenism « and seems to have started from the seventh century on. ${ }^{2}$ Nevertheless,

* Correspondence details: Dr. Christian Gastgeber, Institute for Medieval Research, Division of Byzantine Research, Austrian Academy of Sciences, Hollandstraße 11-13, 1020 Vienna, Austria; email: Christian.Gastgeber@oeaw.ac.at.

1 The documents that are discussed in this article will be presented with their original or contemporary terms in order to avoid a misunderstanding by using translated modern terms. In the tables 2-3 the legal texts are summarised under novella (including edicts).

2 Cf., e.g., the shape of the note of recognition legimus in imperial documents: Dölger and Karayannopulos, Byzantinische Urkundenlehre, 35 and fig. 12a-12f. On exhellenism in legal texts, see Troianos, Römisches Recht. 
the Byzantine emperors had to maintain at least some Latin words in their documents in order to emphasise their claim of being the "Emperor of the Romans (basileus ton Rhomaion). Therefore, even in Greek documents such terms and phrases were written with Latin letters; but their shape was noticeably changed and in some documents reveals an artificial attempt to draw letters and words with which a notary of the imperial chancery was no longer familiar. ${ }^{3}$ It goes without saying that epigraphy, numismatics and sigillography will further contribute to a more complete overview of the use and local particularities of Latin as far as respective witnesses are preserved. In this study I shall not tackle the huge research question of the Hellenism of the Byzantine Empire ${ }^{4}$ and of the interaction between Greek and Latin, but shall confine myself to the early documents of the imperial chancery - including all the problems with which the transmission of these texts confronts us.

The main problem with the documents of the early period is the fact that no text is preserved as an original, but only as a copy in collections of laws, letters or council acts; ${ }^{5}$ these collections provide text versions full of typical scribal errors and modifications, ${ }^{6}$ in both languages, Latin and Greek. Furthermore, some of them still need to be critically edited, a basic desideratum for a linguistic approach and another reason why this study can only serve as the initial access to the topic. The first original witness to a Western addressee, the so called "Kaiserbrief " (imperial letter) of St. Denis, a papyrus dating from the second quarter of the ninth century, ${ }^{7}$ is written in Greek alone and does not seem to have been accompanied by a Latin translation. After a gap of more than 250 years, a new wave of preserved original letters to the West (to the pope) started from 1139 on, ${ }^{8}$ original contracts as much as half a century later, from 1192 on. ${ }^{9}$ Only from this time onwards are authentic and secure data about the shape, layout, script and text presentation in the documents provided.

The Byzantine Empire "started« as the successor or heir to the Roman Empire and consequently used Latin in its higher administration and, at least, in West-oriented contacts. Legal decrees that were issued by the emperor for the whole empire were written in Latin. A remarkable modification is evident under Emperor Justinian I who started (or continued?) ${ }^{10}$ issuing his novellae in Greek and/or Latin depending on the target audience. Thanks to the meticulous studies by Wolfgang Kaiser, ${ }^{11}$ we have a good impression of the practice of how

3 See Chitwood, Byzantine Legal Culture, 159-162 (with references to former studies).

4 See, e.g., the recent study by Kaldellis, Hellenism.

5 The rare exceptions of documents preserved in other collections are presented in the list below.

6 A particular case is the forgery (or »revised version«) of the privilege for Archbishop Maurus of Ravenna, cf. below on regest 233 .

7 Dölger et al., Regesten 1, 1, 216 (regest 413: the date attributed to this letter, May 827, is not convincing; unfortunately, a critical discussion on the date is missing).

8 Dölger and Wirth, Regesten 2, 195-196 (regest 1320a: June 1139), cf. also the next preserved originals: 196-197 (regest 1320b: April 1141) and 206 (regest 1348: August 1146).

9 Dölger and Wirth, Regesten 2, 306-308 (regest 1607: February 1192, for Pisa).

10 Kaiser and Chronopoulos, Unterschiede, 495-499 (discussing bilingual issues of two constitutiones of Emperor Theodosius II [23rd March 431, 3rd August 435]).

11 See Kaiser, Zweisprachigkeit; Kaiser and Chronopoulos, Unterschiede; furthermore, the detailed studies on particular collections of Justinian's novels, Kaiser, Epitome Iuliani, and Kaiser, Authentizität. 
legal decrees were issued. To sum up his results, Justinian issued his novellae to the Latinspeaking areas of his empire (Northern Africa, Italy, Latin parts of Illyricum $;{ }^{12}$ the addressee was generally the respective praefectus praetorio) in Latin, and to the Greek-speaking areas in Greek. ${ }^{13}$ Novellae that concerned the entire empire were issued in Greek and Latin. ${ }^{14}$ The latter finding resulted from Kaiser's critical revision of all texts and manuscripts which had to correct the former study by Ernest Stein assuming that universal novellae were issued in Greek alone. ${ }^{15}$

With the end of one common (Western and Eastern) Empire and the continuity of the Roman Empire in the East, the situation changed: the need for and use of the former administrative language, Latin, decreased; Greek became the official language of administration since the lower officials of the Eastern areas no longer understood Latin. Even in the capital, the practice and knowledge of Latin were on the decrease, which entailed the following development:16 the shaping of Latin phrases and legal terms originating from Latin times became increasingly artificial, thus indicating that the scribes were no longer familiar with the Latin language and script. Due to such linguistic shortcomings, the Byzantine East transmitted only what was rendered into Greek.

It remains an open question when the chancery finally switched to Greek in imperial legal decrees concerning the entire empire (and promulgated in all parts of the empire) and, in a next step, also in the correspondence with the West. The two cornerstones are, on the one hand, Justinian I, who initiated the process and, on the other hand, Leon III (and Constantine V), who issued their ecloga in Greek alone. By reviewing the documents under this aspect, I shall try to elaborate the stages towards the new practice. If a legal order that concerns the entire empire is issued only in Greek, it is important evidence that Latin-speaking regions are actually no longer addressed in their own language. We are on the safer side if documents like personal letters are directed to Latin-speaking addressees in Greek alone. Both cases are present in the documents that we shall discuss below.

The analysis would be easy if the texts were transmitted in their original languages, but some Latin documents confront us with the problem that they can represent the original Latin versions or translations, which, furthermore, have to be differentiated as official or unofficial versions. Four possibilities have to be taken into consideration: 1) an original Latin text from the chancery (alone or together with a Greek version which may be based upon a Latin draft or this Latin document); 2) an official Latin translation (from a Greek original) by the chancery in Constantinople (to be promulgated together with the Greek original), 3) an unofficial, so called kata poda Latin translation (of the Greek original) in Constantinople or in another law school city with the object of teaching imperial laws to Latin-speaking students, or 4) an unofficial local Latin translation (of the Greek original) by the addressee of a

12 See Kaiser, Zweisprachigkeit, 394-395, 460-472 and the detailed analysis of novella 32 of 15 th June 535 in Kaiser and Chronopoulos, Unterschiede.

13 Kaiser, Zweisprachigkeit, 393-395.

14 Kaiser, Zweisprachigkeit, with the summary 472-474.

15 Stein, Deux questeurs, 383-390 = Stein, Opera, 377-384; see also Kaiser, Zweisprachigkeit, 395-396, 441-447 (Greek translation of novella 111 in the so-called collection of 13 edicts in ms. Marcianus gr. Z 179).

16 See Burgmann, Lateinische Wörter. 
legal decree in order to understand the Greek text. Generally, the manuscript transmission of a text in one of the two languages is a priori no safe indicator of the linguistic authenticity. A famous example is the heterogeneous transmission of Justinian's novellae, which led to very different statements among law history experts. ${ }^{17}$ However, the detailed studies by Wolfgang Kaiser seem to have solved this question, coming to the aforementioned conclusion that under Justinian novellae concerning the entire empire were issued in Greek and Latin. ${ }^{18}$ The problem with this research is that no universal novella is preserved in Greek and Latin as officially issued by the imperial chancery. Greek and Latin versions of the same novella do exist; however, the Latin versions are not products of the imperial chancery, but auxiliary translations in a law school for students who were not familiar with Greek and were provided with a kata poda translation which follows the Greek text closely in word order and grammatical construction. Finally, the problem does not end at the point of three Latin translation categories; it is even possible that an original Latin version was rendered into Greek as a kata poda translation for Greek students. ${ }^{19}$

\section{Overview of the Documents, their Transmission and Language}

In order to base the results on a solid fundament, I shall first present the textual witnesses under all relevant aspects. Since Kaiser's research on the language of Justinian's novellae raises awareness of the text transmission, the addressee of a document and its linguistic authenticity, I shall include these features in the list below. ${ }^{20}$ Under "characteristics " I shall summarise the content or important aspects regarding the addressees and the language.

For each emperor I shall add short biographical data about their origins and maternal language, as far as the sources inform us about these data; originating from Constantinople or having previously dwelt there is not pointed out (e.g. for the sons of emperors). The list ends with Emperor Leo III and his edition of laws (for his entire empire) in Greek.

Linguistic particularities of some phrases that require additional comments regarding the original language will be discussed in the succeeding paragraph.

17 See Kaiser, Zweisprachigkeit, 393-396, with summary on the research. A general overview of Justinian's novellae and the collections is provided in Kearley, Creation.

18 Kaiser, Zweisprachigkeit.

19 See Kaiser, Zweisprachigkeit, 439-448 (novella 111 of 1st June 541).

20 This list is based on Dölger et al., Regesten 1, 1 (quoted by the regest number). Unfortunately, the recently revised edition of the regests is partially flawed and lacks essential information (e.g. about the manuscript transmission of the documents), controversial statements are not explored in greater depth, or the most recent study is taken as authoritative. - I include here only regests which relate to a transmitted text and exclude forgeries (except for regest 233, since this text is included in Regesten as an authentic version) as well as novellae which are known by their titles alone (like regests 69-74, 133a, 144, according to a manuscript index of lost pages). Furthermore, documents which are too fragmentary or suspect to base linguistic research on them (like regests 79d, 161) are not taken into account. Documents which are preserved as a direct quote in a Latin or Greek historical work are marked against a blue background, since they are generally suspect of being linguistically revised or adapted (documents that are preserved only in Syrian [regests 203, 221], Armenian [regest 280a] or Georgian [regest 302c] are not included here). 
Seven (Greek only) novellae of the first (co-)emperors Justin $\mathrm{II}^{21}$ and Tiberius $\mathrm{I}^{22}$ are included in the big official corpus of Justinian's Greek novellae, the so-called collectio CLXVIII novellarum (collection of 168 novellae), which is preserved in two main mss. Marcianus gr. $\mathrm{Z}$ 179 and Laurentianus Plut. 80, 4 + Leidensis Perizonianus F $35 .{ }^{23}$ In addition, the Greek versions of the novellae are also transmitted in some compilations from which I shall quote the Breviarium of the scholasticus Theodorus of Hermupolis in Egypt ${ }^{24}$ (active in Constantinople 575-602) and the Syntagma of the scholasticus Athanasius of Emesa ${ }^{25}$ (composed in Antioch [?] in the last quarter of the sixth century). ${ }^{26}$

21 novellae 140, 144, 148 and 149.

22 novellae 161,163 and 164.

23 See the description in Kaiser, Zweisprachigkeit, 397-404.

24 See Kaiser, Initia; and the introduction to the critical edition by Zachariae von Lingenthal, esp. XLVII-LI.

25 See Simon, Novellenexemplar; Kaiser, Zweisprachigkeit, 411; Kaiser, Initia 509-514; and the introduction to the critical edition by Simon and Troianos.

26 On the abbreviations used in this list, see at the end of the article. 


\begin{tabular}{|c|c|c|c|c|}
\hline 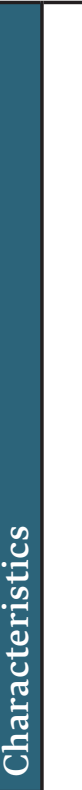 & 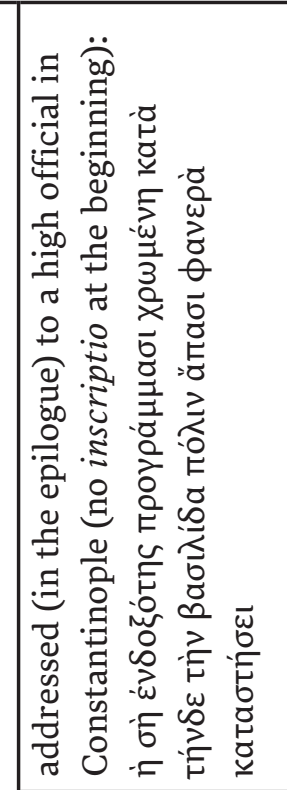 & 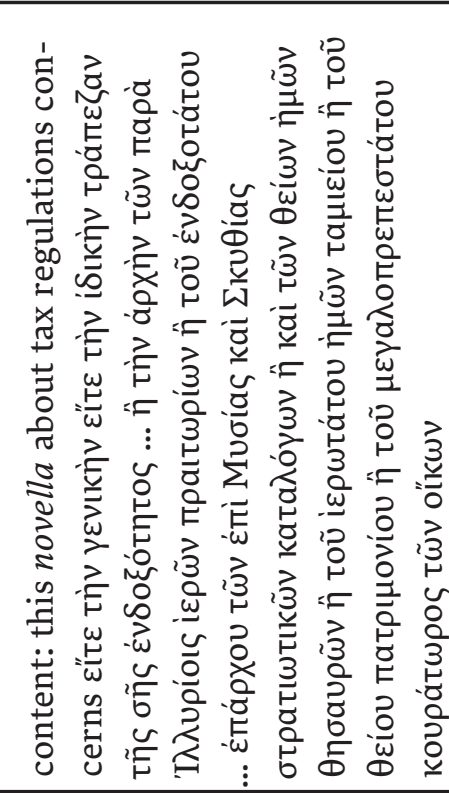 & 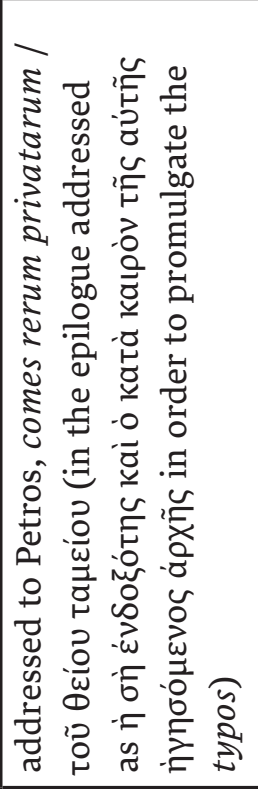 & 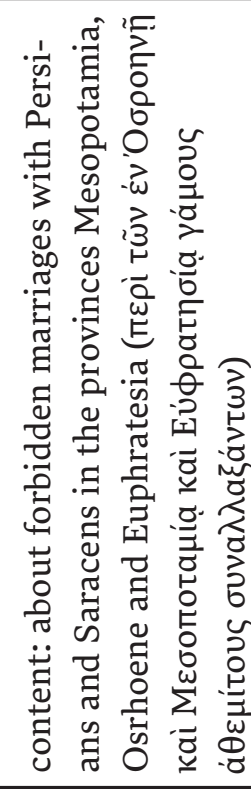 \\
\hline 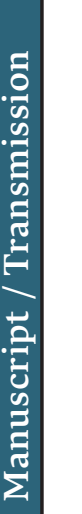 & 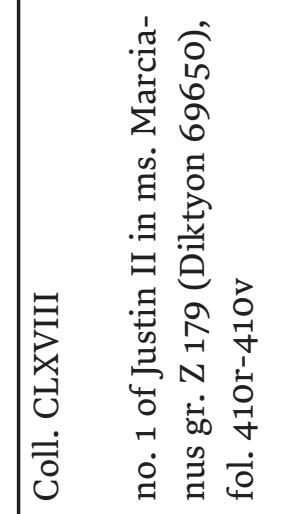 & 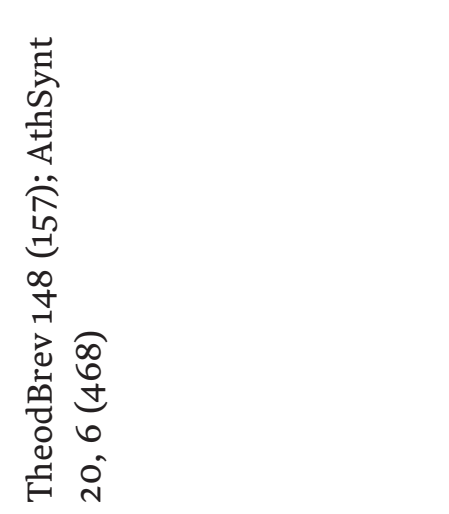 & 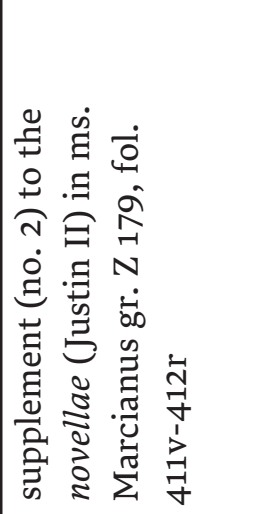 & \\
\hline 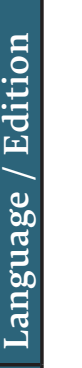 & 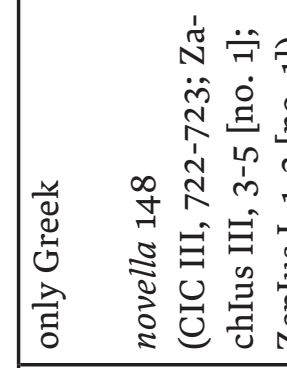 & & 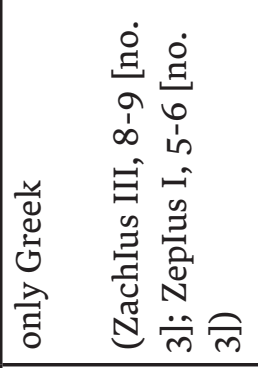 & \\
\hline 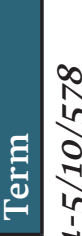 & 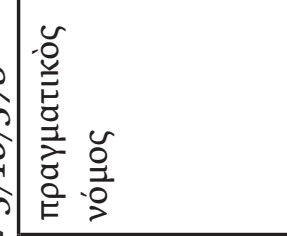 & & 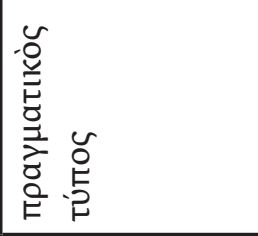 & \\
\hline 范 & $\begin{array}{l}0 \\
\text { in }\end{array}$ & & 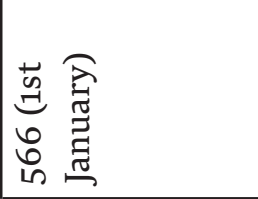 & \\
\hline 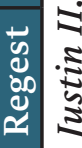 & + & & in & \\
\hline
\end{tabular}



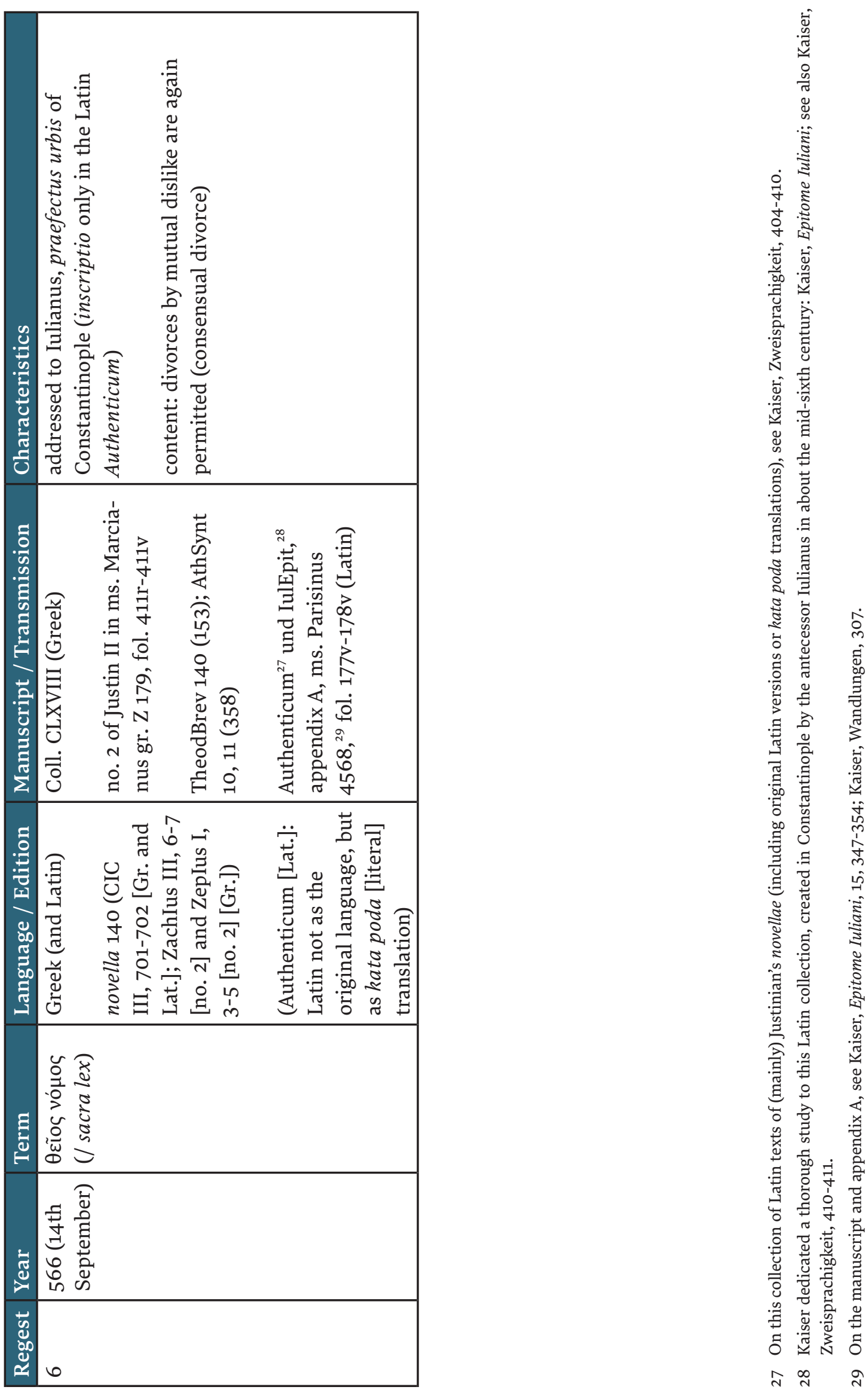

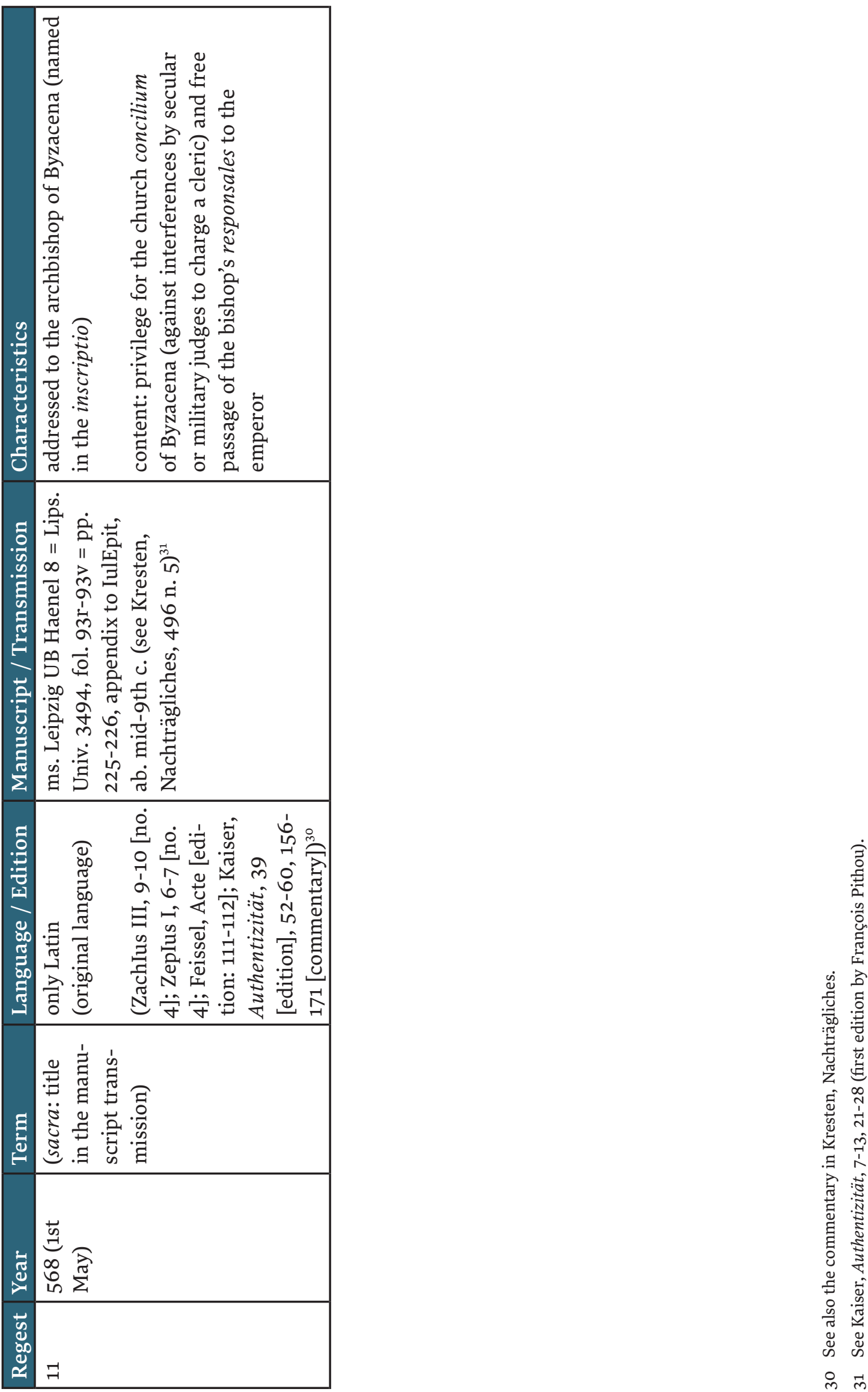


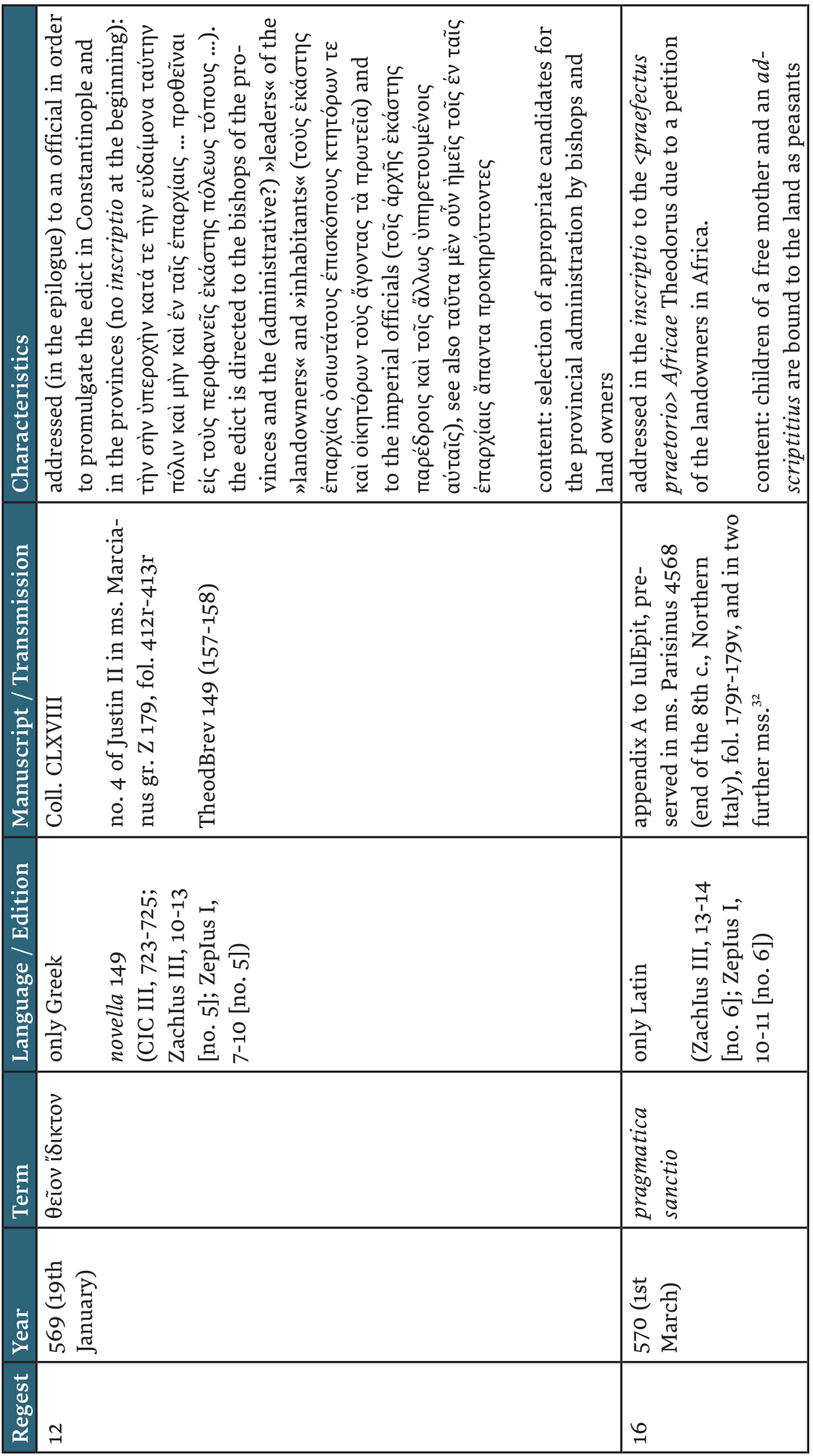




\begin{tabular}{|c|c|c|c|c|c|}
\hline 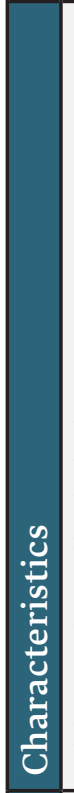 & 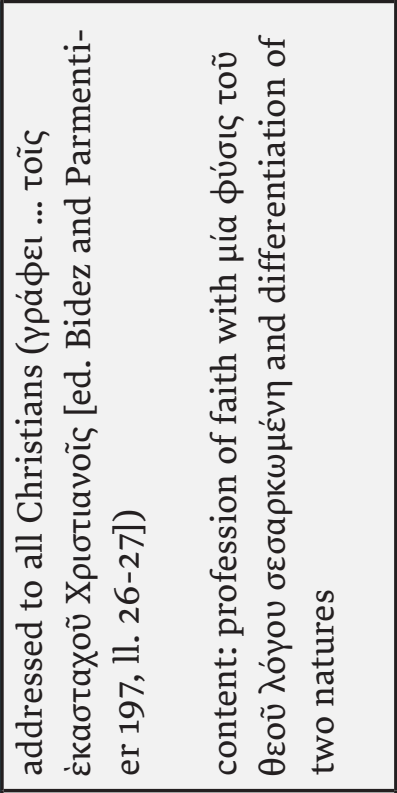 & 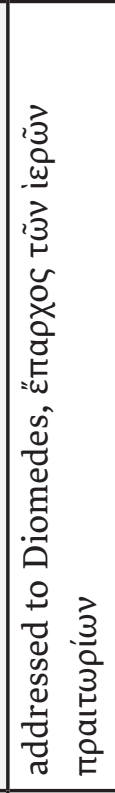 & 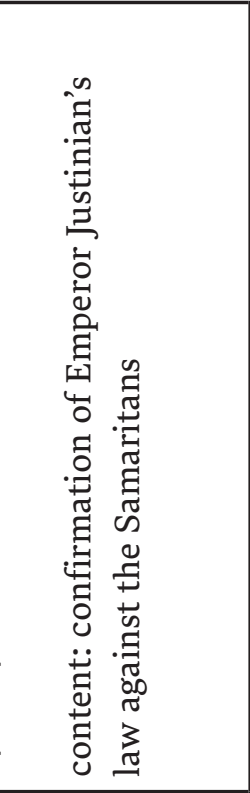 & 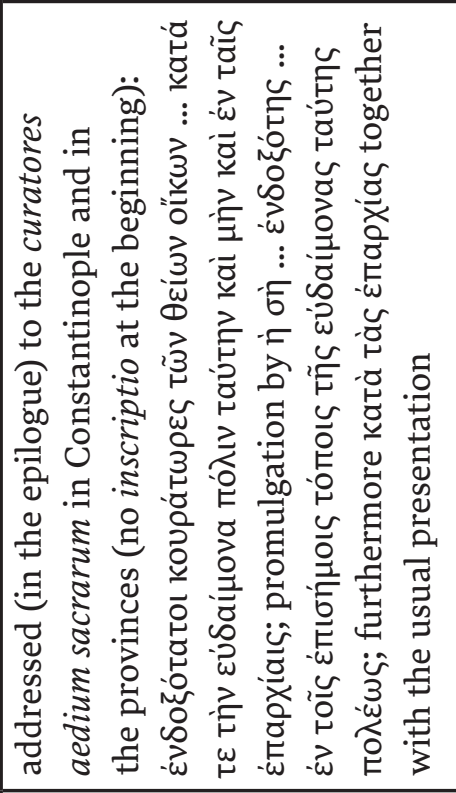 & 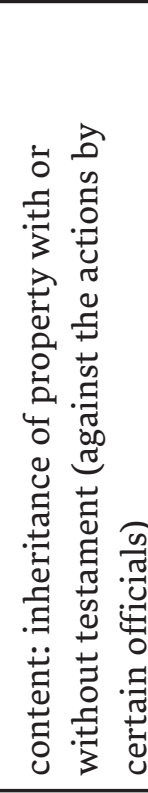 \\
\hline 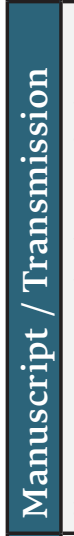 & 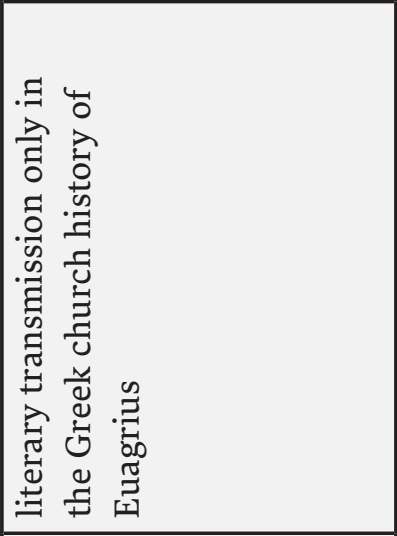 & $\begin{array}{l}1 \\
\\
0 \\
0 \\
\overline{0} \\
0\end{array}$ & 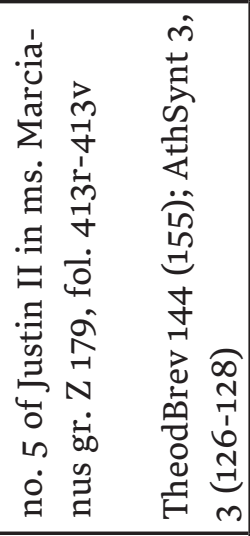 & 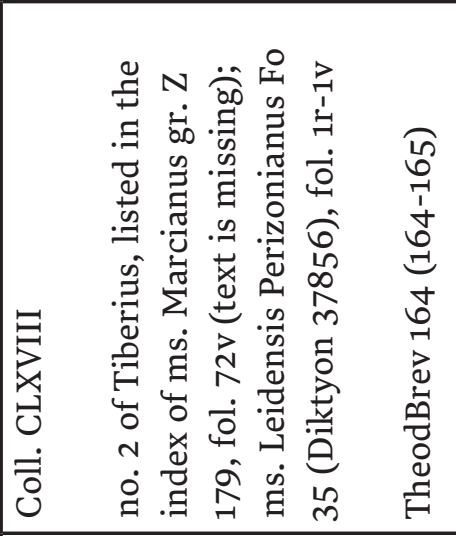 & \\
\hline 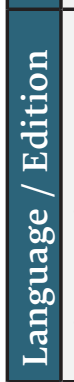 & 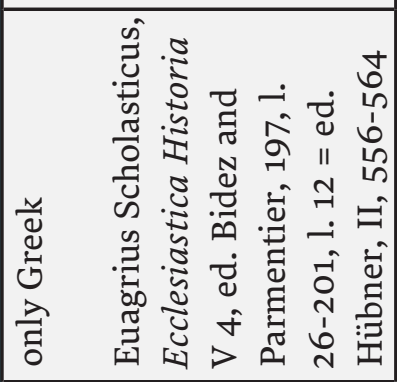 & 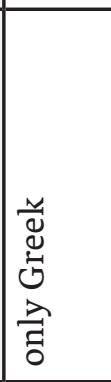 & 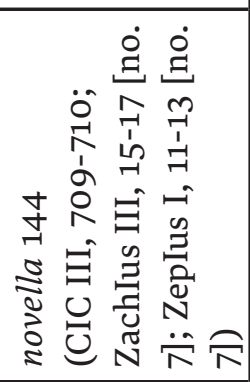 & 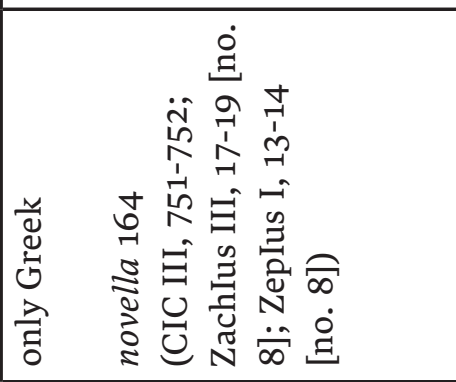 & \\
\hline 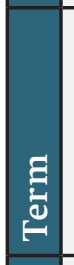 & 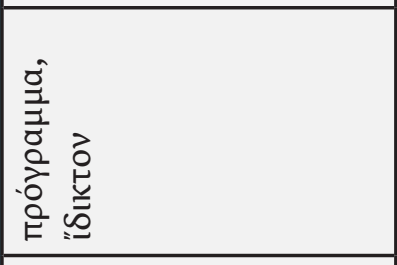 & 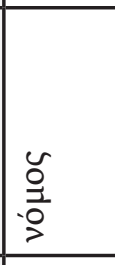 & & 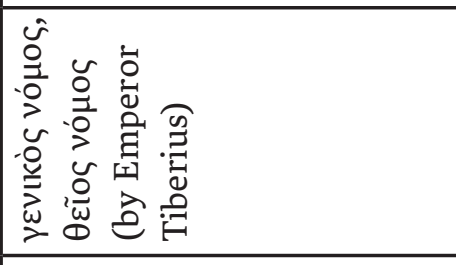 & \\
\hline$\stackrel{\pi}{\varpi}$ & 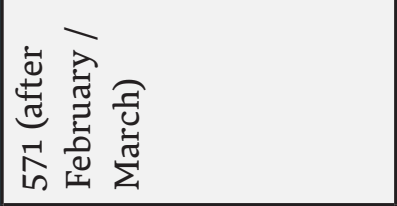 & $\underbrace{\substack{\infty \\
\infty}}_{\substack{n \\
N}}$ & & 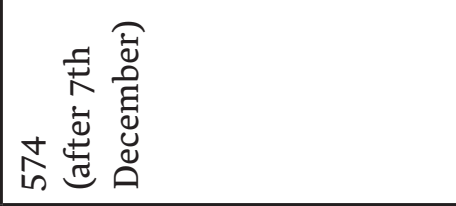 & \\
\hline$\left|\begin{array}{l}0 \\
0 \\
0 \\
0 \\
\approx \\
\approx\end{array}\right|$ & I) & $\stackrel{10}{N}$ & & & \\
\hline
\end{tabular}




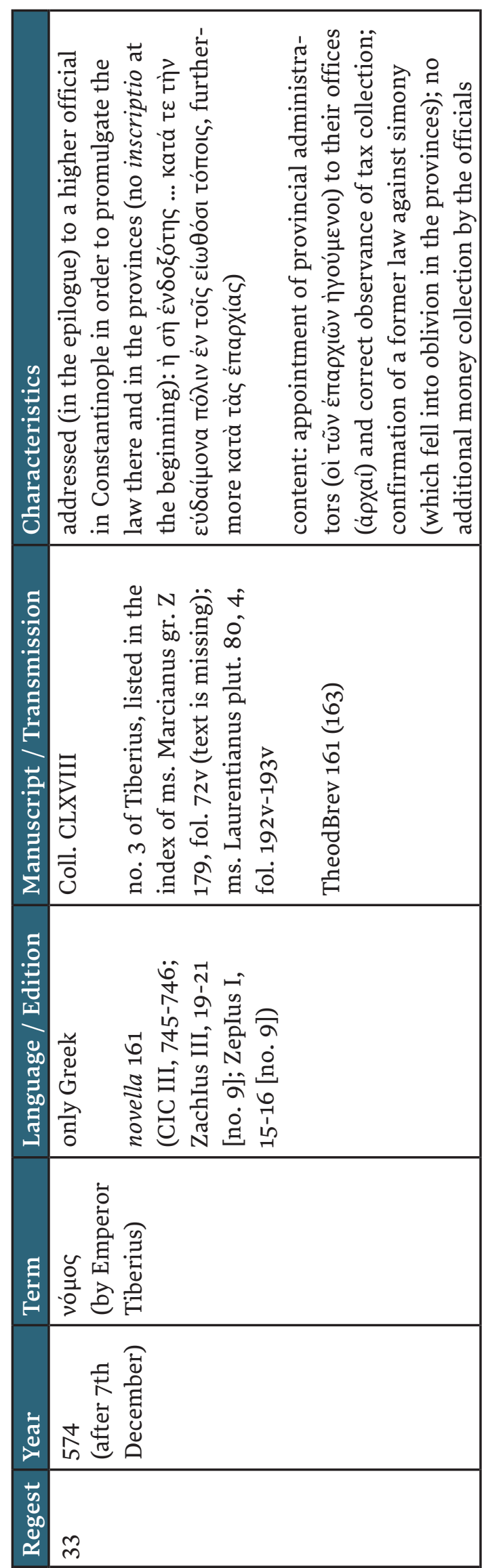




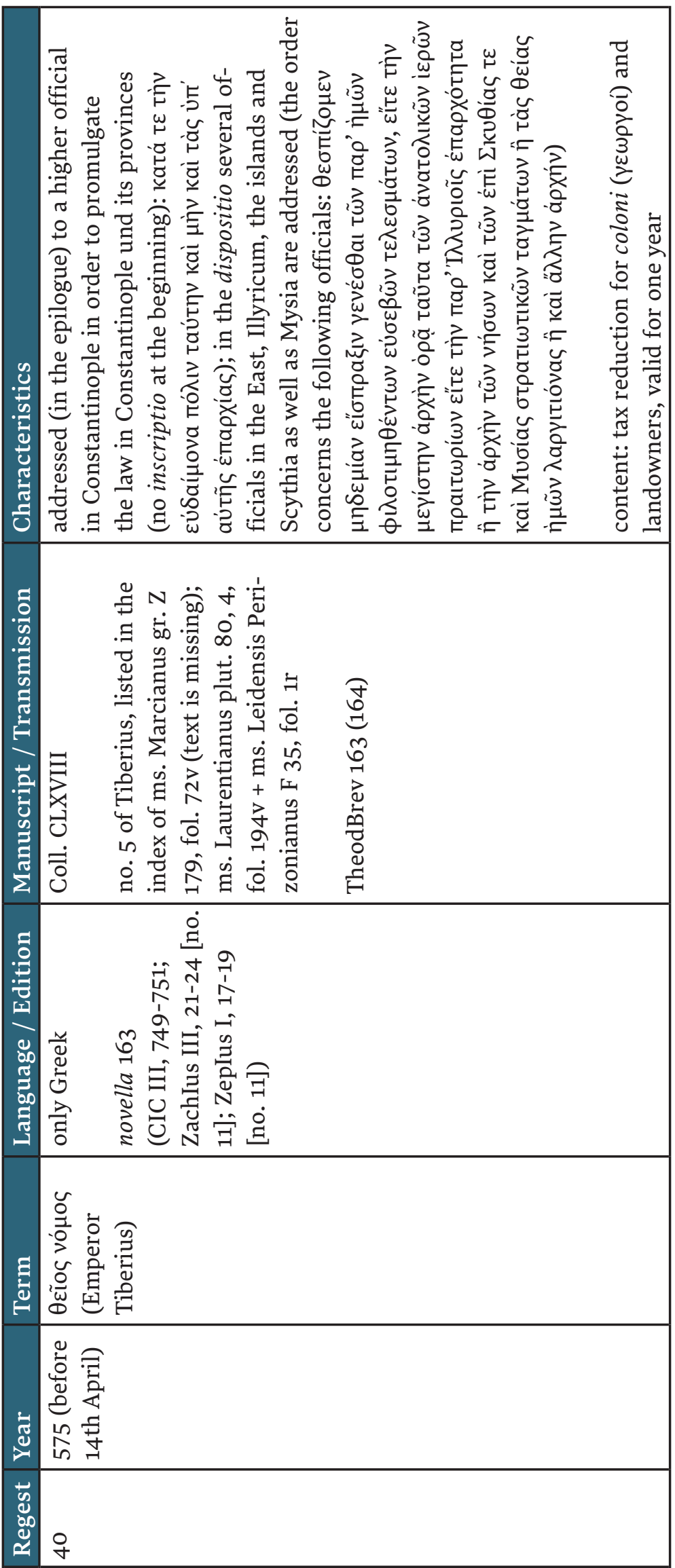




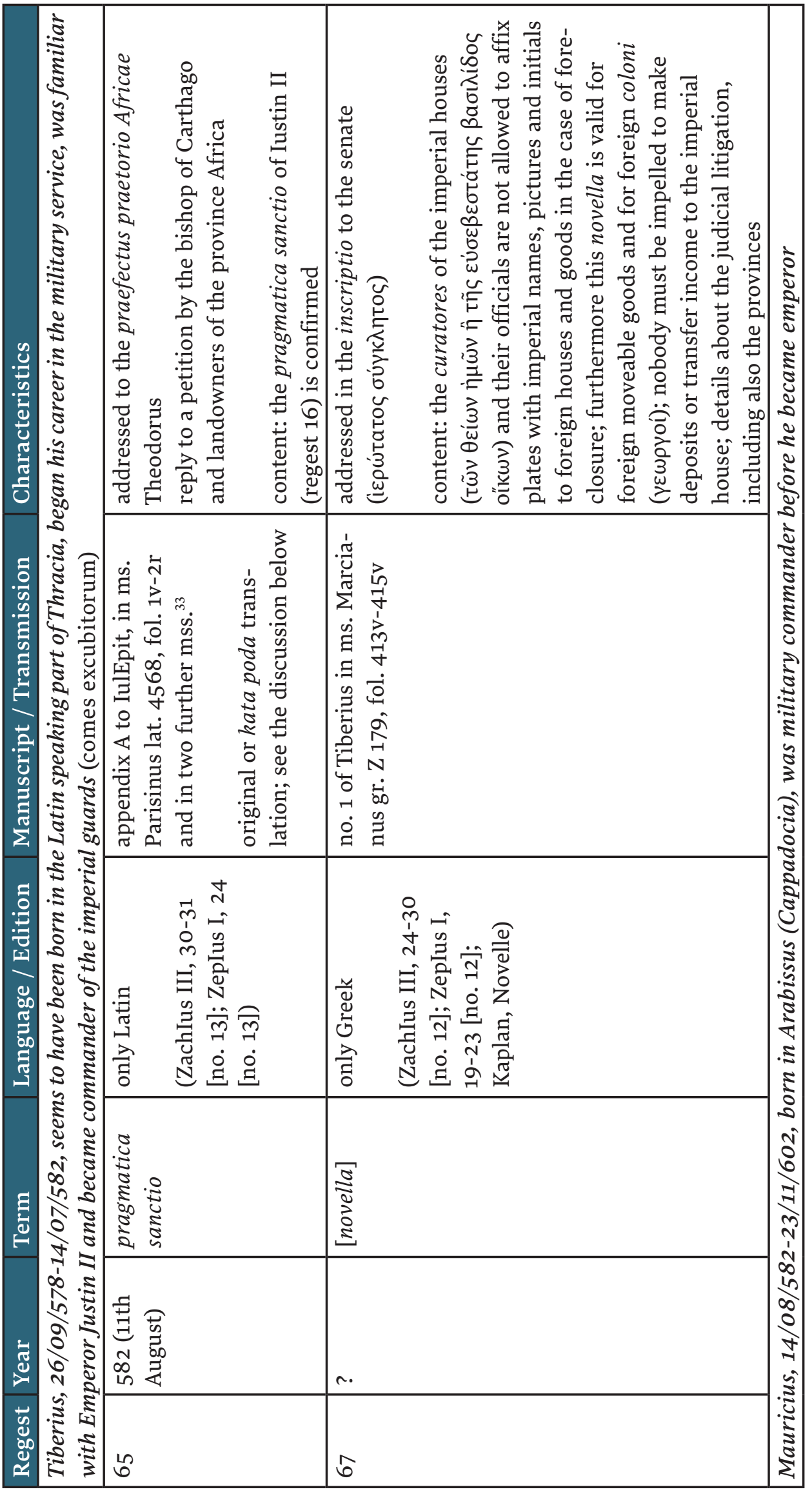




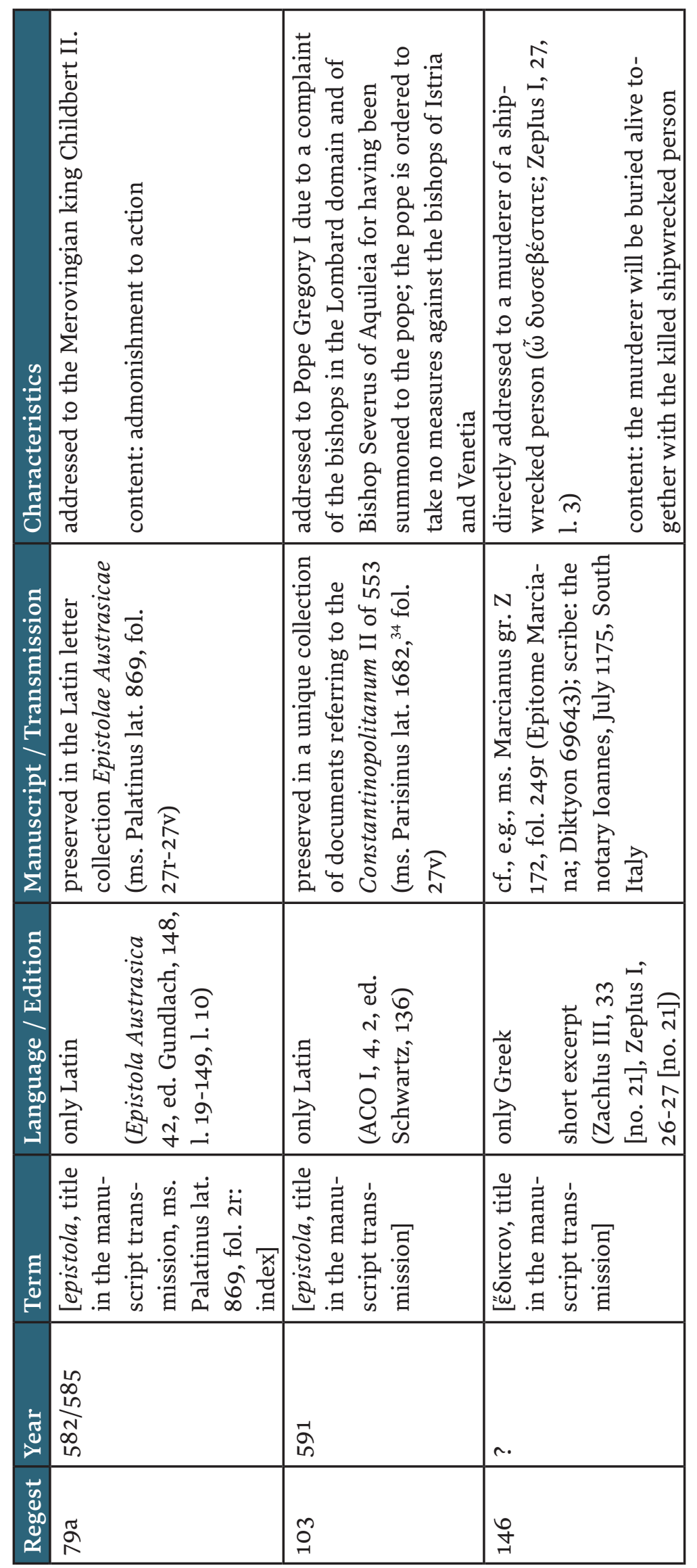




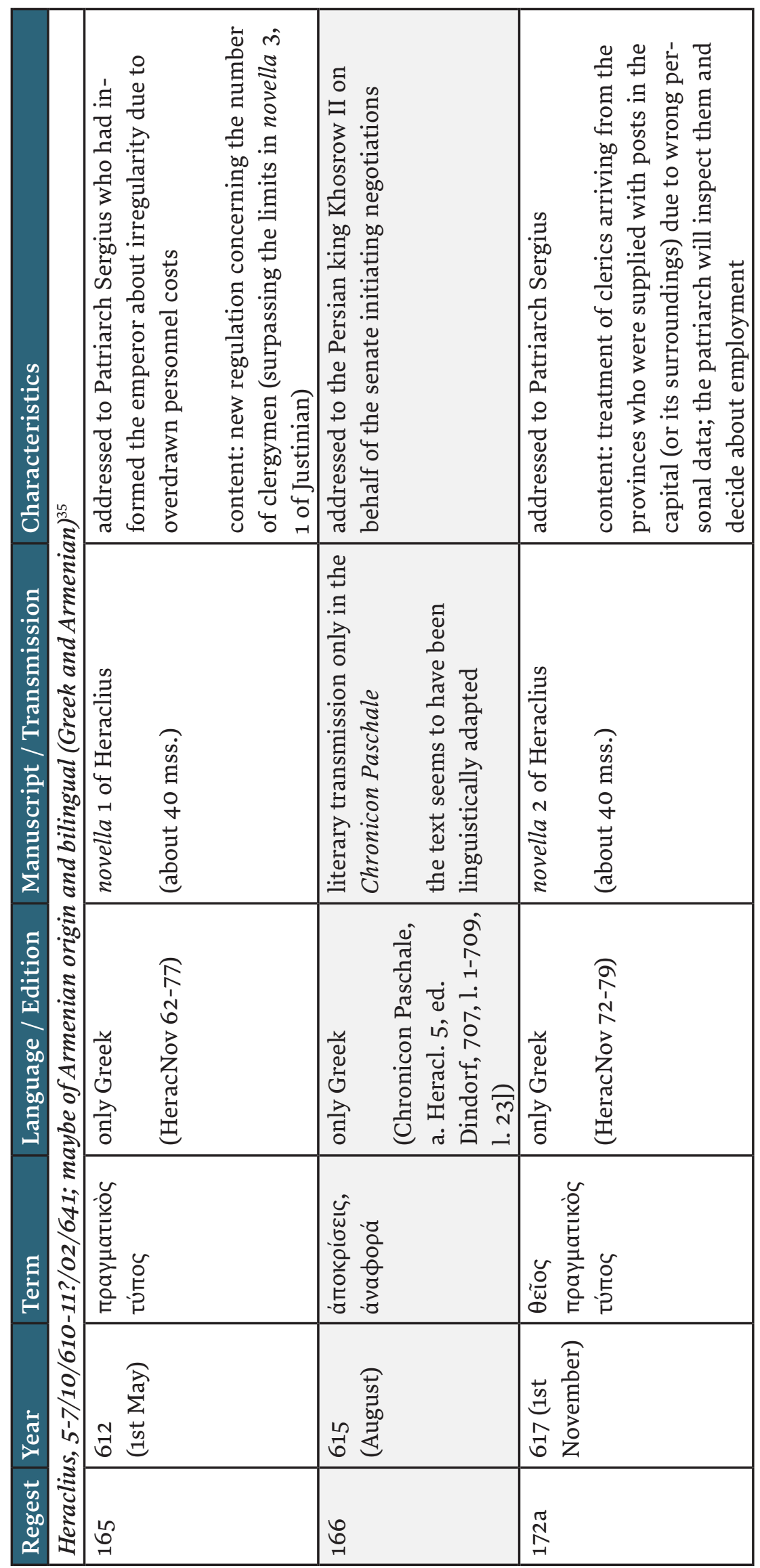




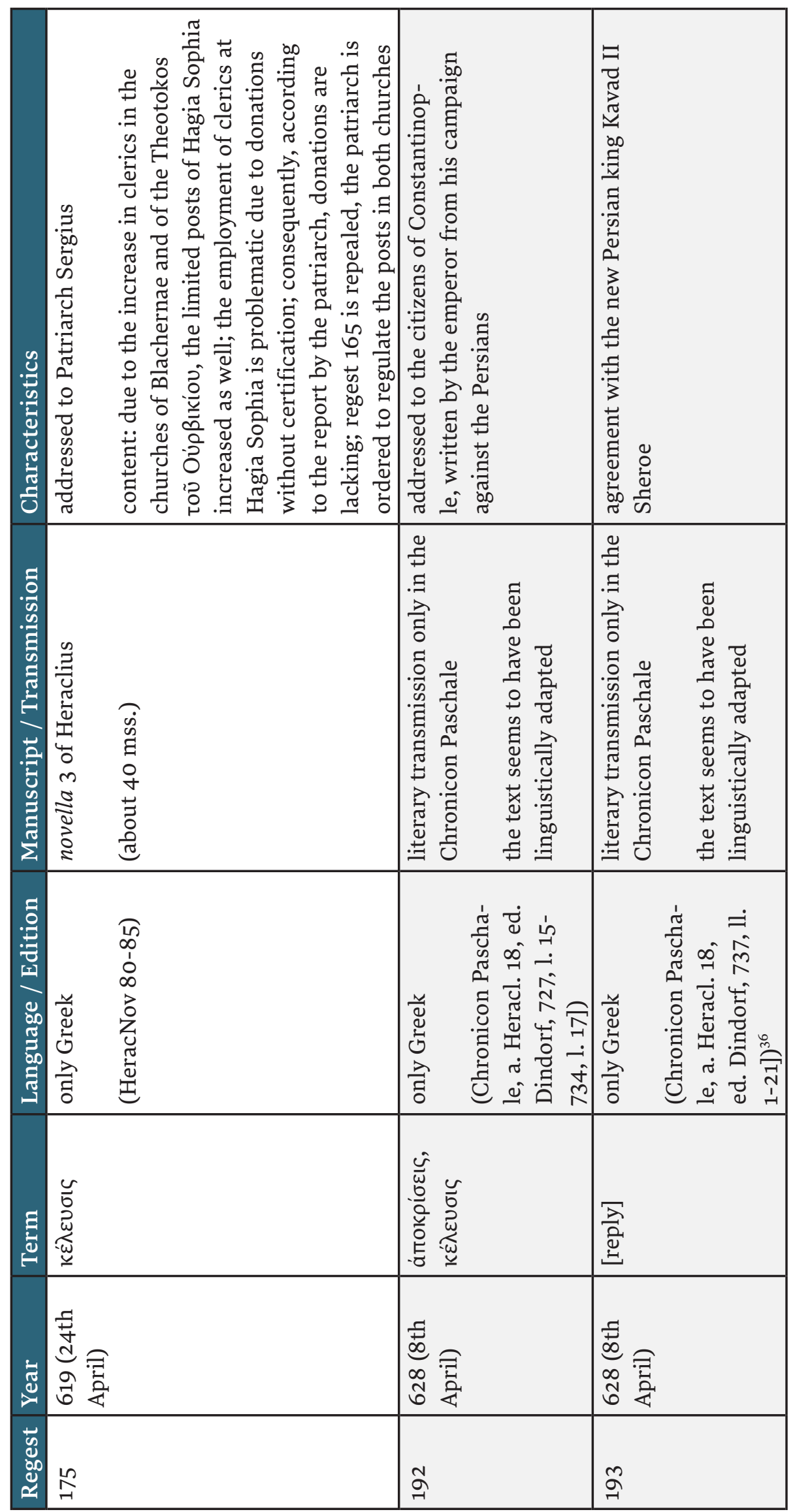




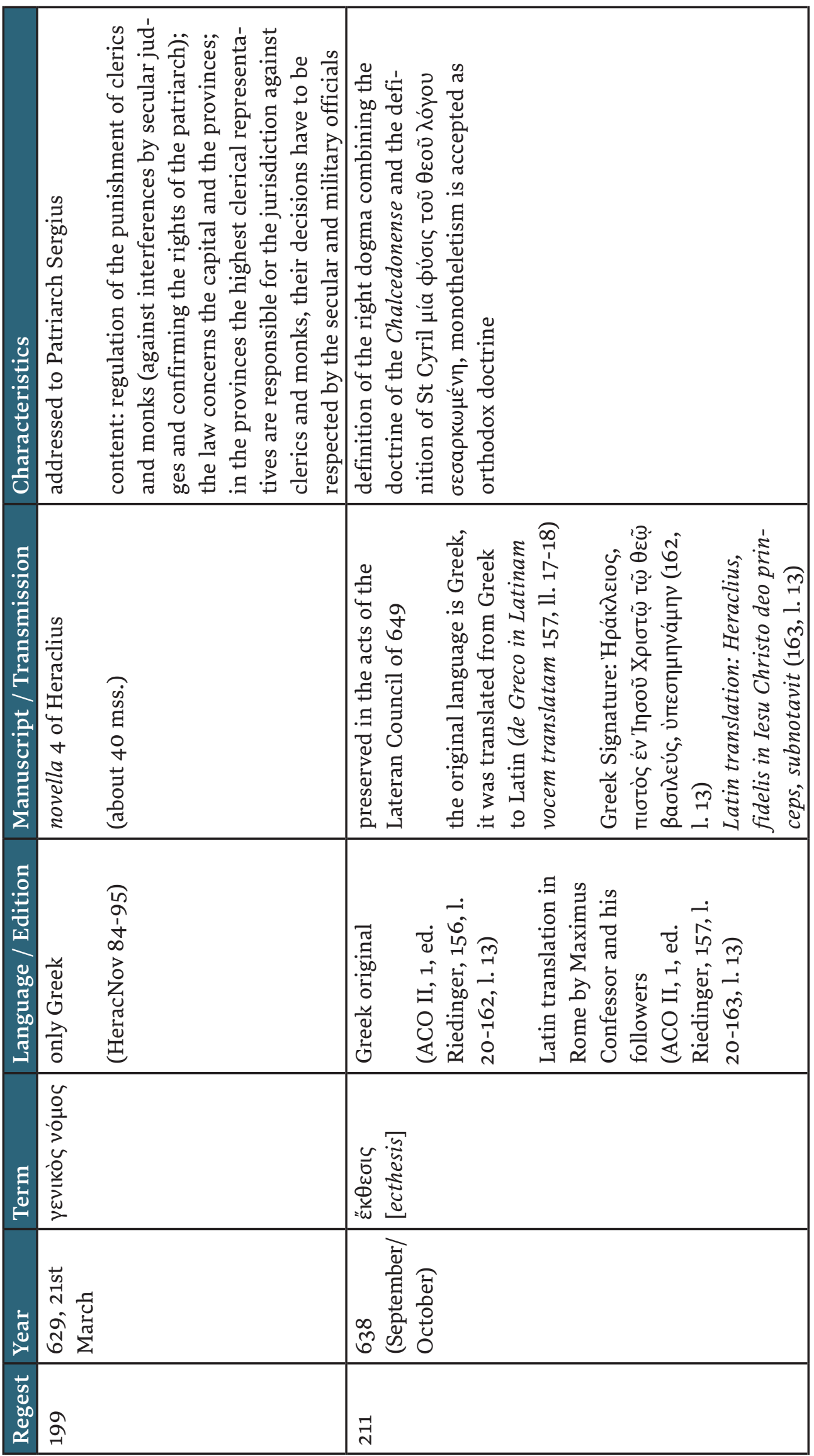




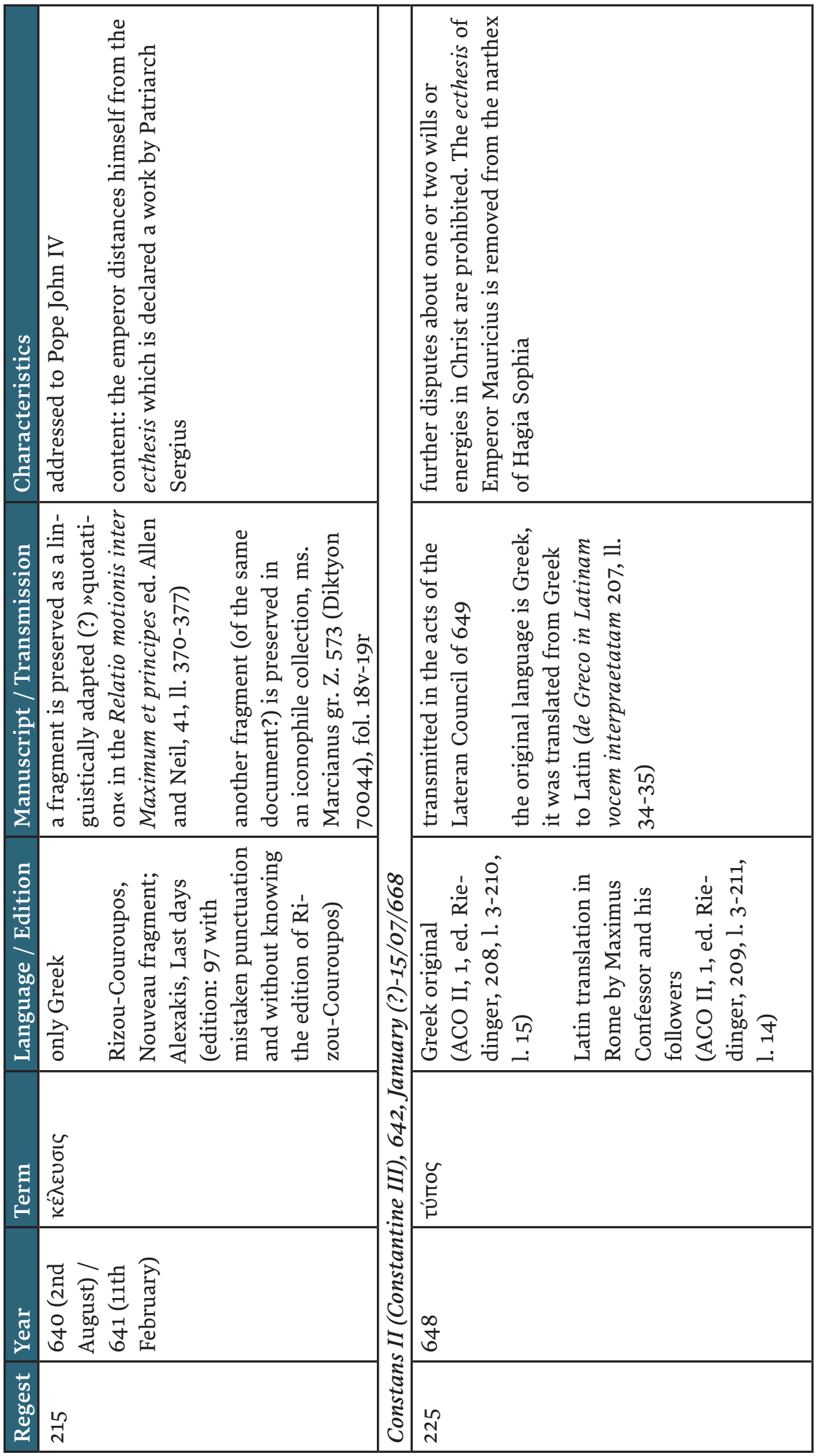



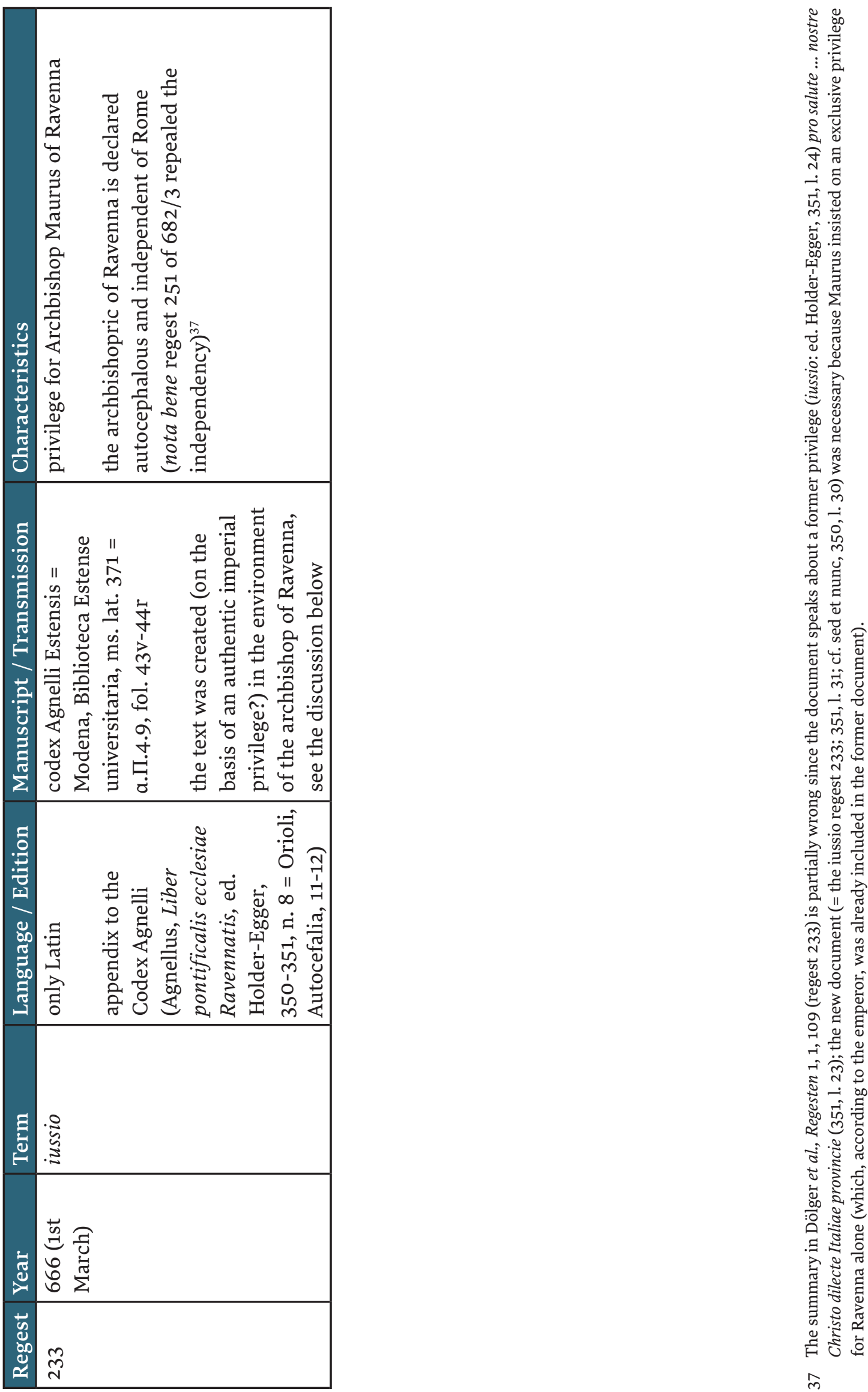

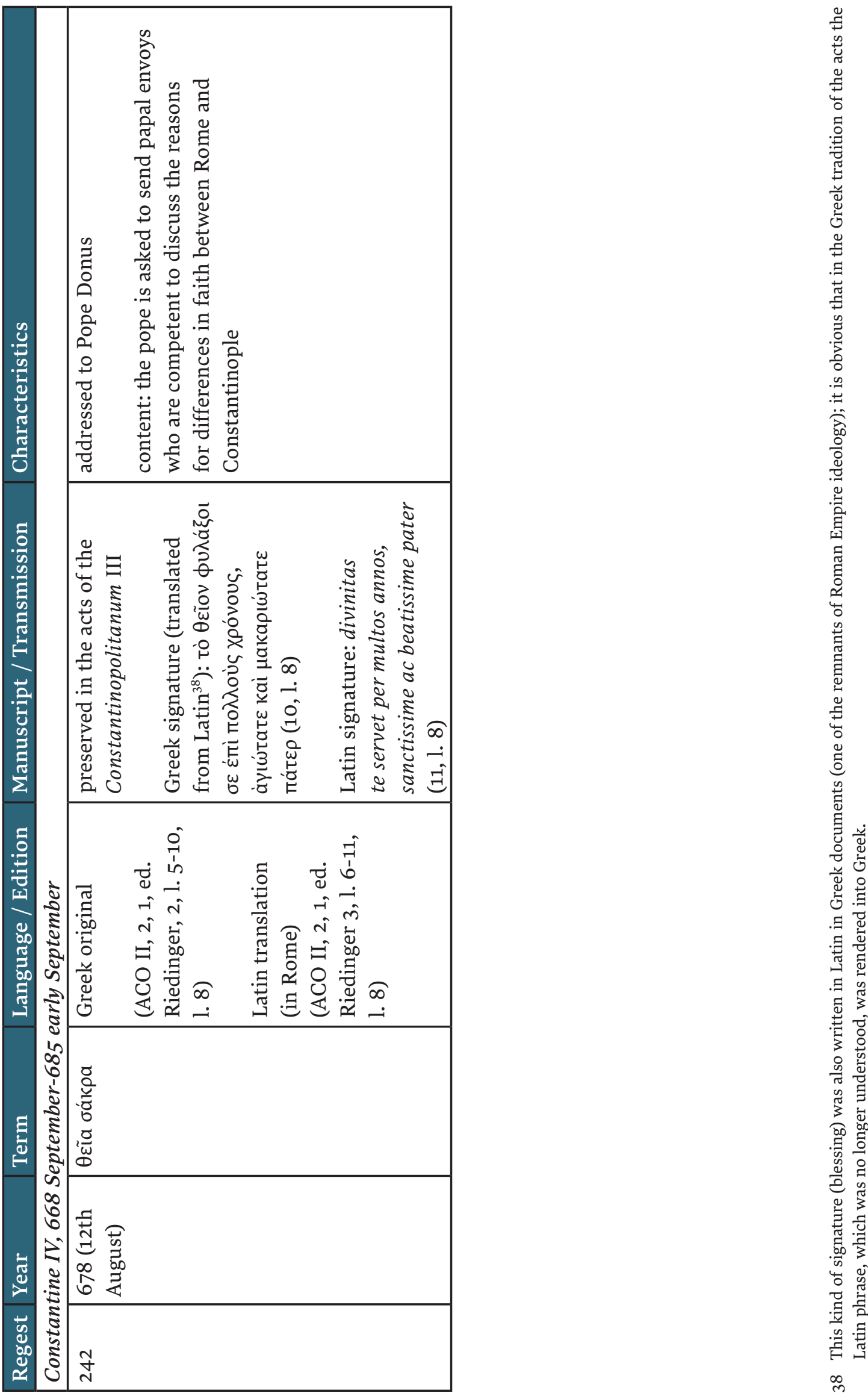


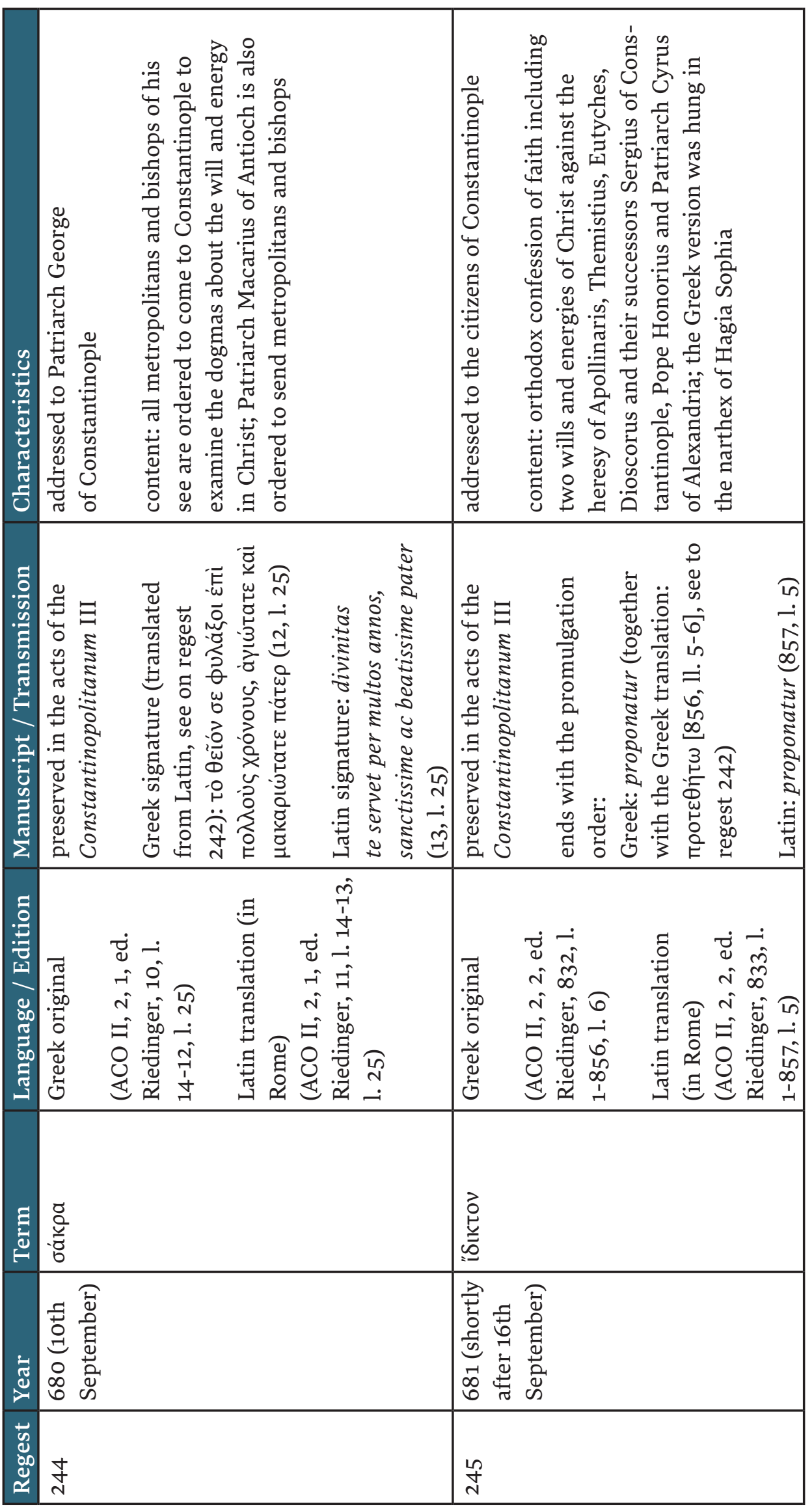




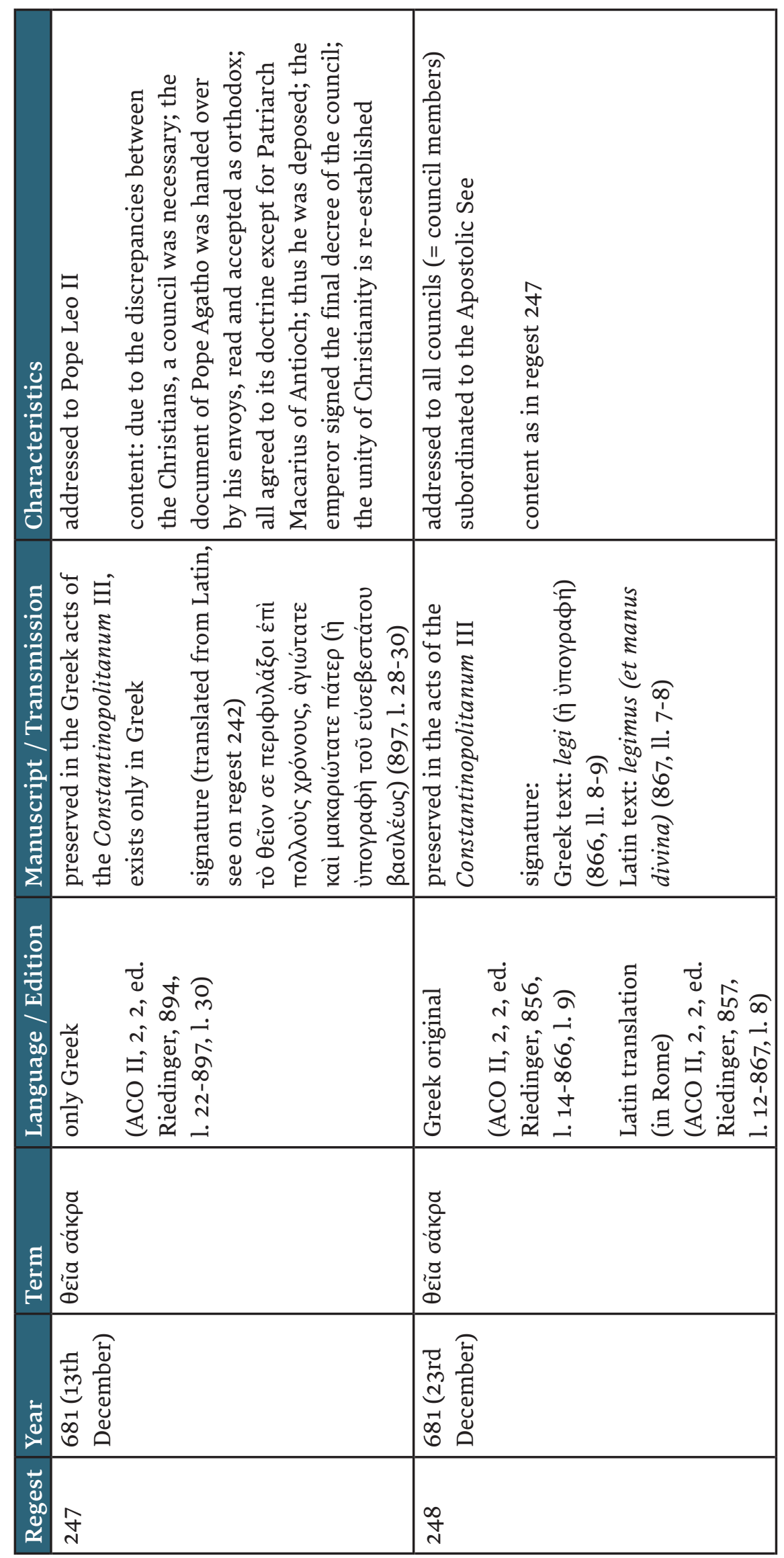




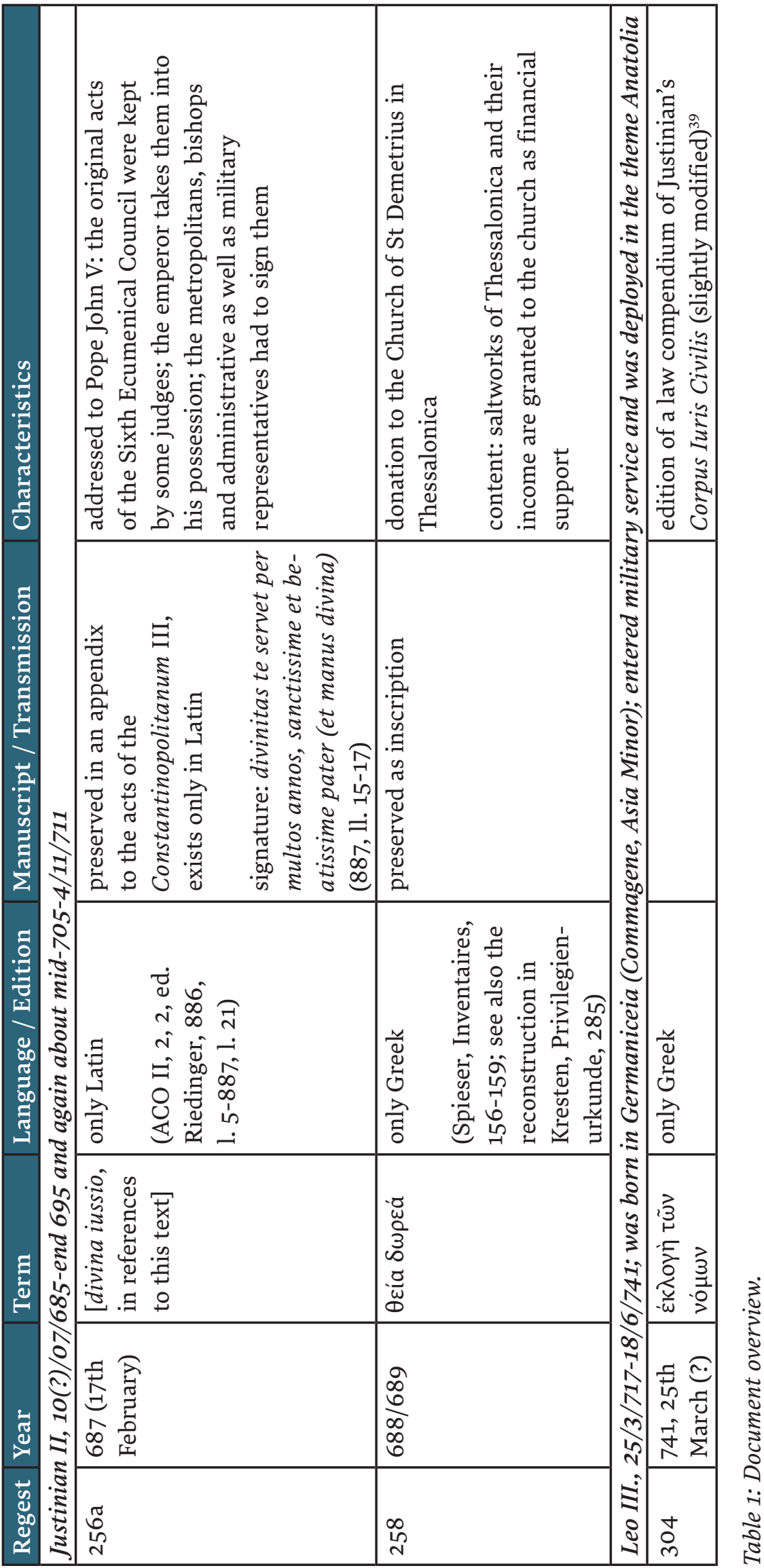




\section{Linguistic Aspects of the Texts}

This section will scrutinise the original language of the chancery products, in particular when (only) a Latin version is preserved. However, a thorough analysis of the respective texts would exceed the space and limits of an article and, as stressed in the introduction, a first approach to the topic. Therefore, I shall confine myself to some exemplary phrases or words which suffice to confirm a statement regarding whether it is the original or a translation. A more complete study will compare the texts with all contemporary literary witnesses; important support for this comparison is provided by the acts of the Lateran Council of 649 and the Sixth Ecumenical Council of 680/1, both in Greek and Latin translation (organised in Rome). These versions provide extensive material giving an idea of what a term meant at that time and how specific phrases and word combinations were rendered..$^{40}$

\section{Justin II}

Under Justin II we expect a priori that Justinian's practice of issuing novellae was continued, i.e. Latin for the West, Greek for the East, and Latin as well as Greek for the entire empire. Table 2, which displays the language usage (alone) in the chancery products, seems to suggest a tendency towards Greek as the official language except for regests 11 and 16. But due to the aforementioned studies by Wolfgang Kaiser, we have to take into account the addressee and the target audience as well. Regests 11 and 16 are addressed to Latin-speaking Northern Africa and appear to be the original versions, at least not kata poda translations; from this we conclude that the chancery still maintained Justinian's system (see Table 3 with differentiation according to language and target audience). Among the preserved Greek novellae, only two concern a particular Eastern area (regests 5 and 25b); here again, the use of Greek matches Justinian's practice. Although novellae that concern the entire empire are transmitted in Greek due to the manuscript evidence, this does not exclude the possibility that a Latin version was issued by the imperial chancery as well, since the Greek texts are directed to the higher Greek (i.e. Eastern) administration in order to promulgate or execute the legal decrees in their area (a complementary authentic Latin version could have been issued for the Latin-speaking parts).

40 Unfortunately, the new critical edition of the acts of 680/1 lacks a Greek-Latin glossary; for the Lateran Council of 649, the editor, Rudolf Riedinger, provided an incomplete index of Greek terms and their Latin equivalents (ACO II, 2, 3). 

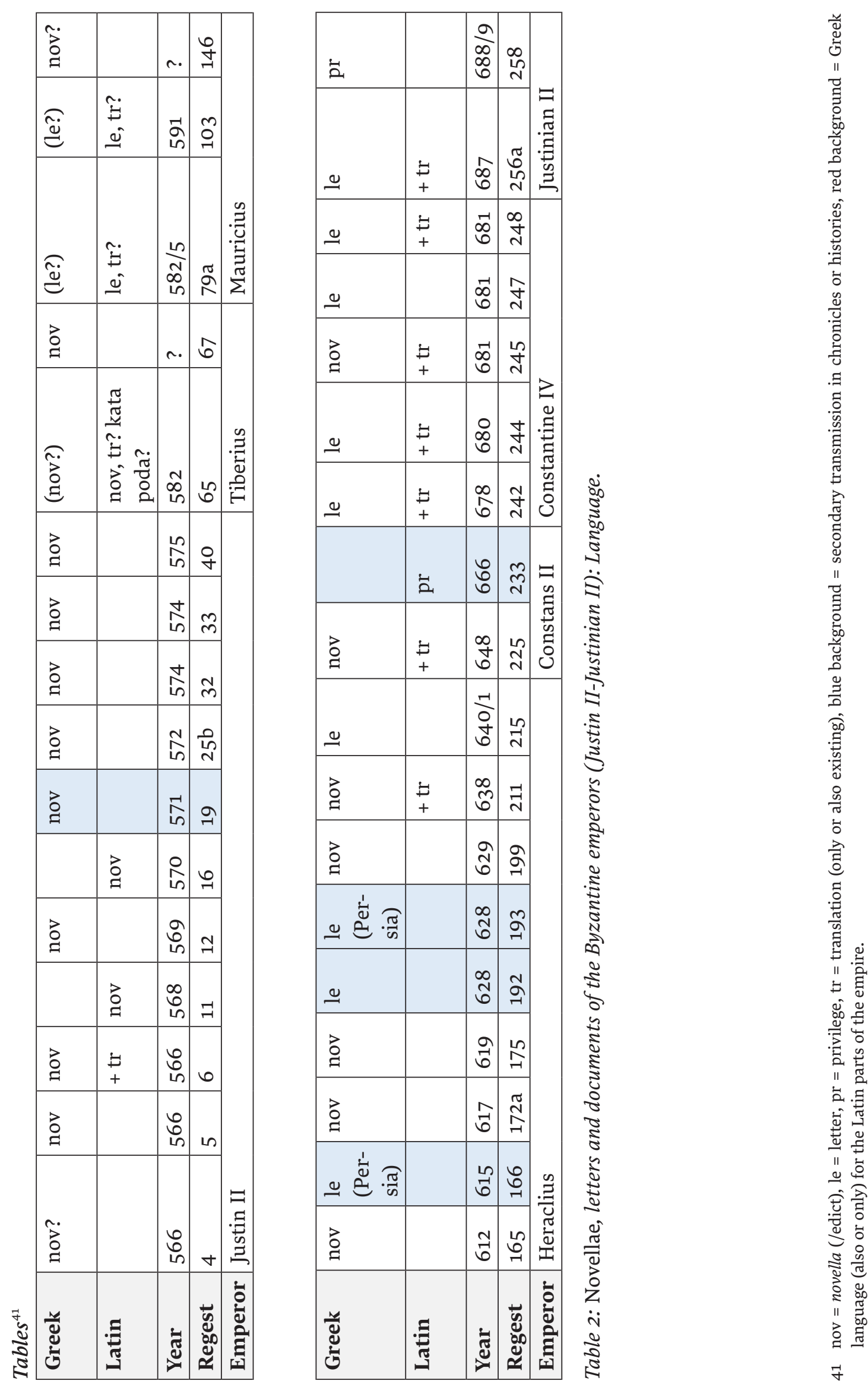


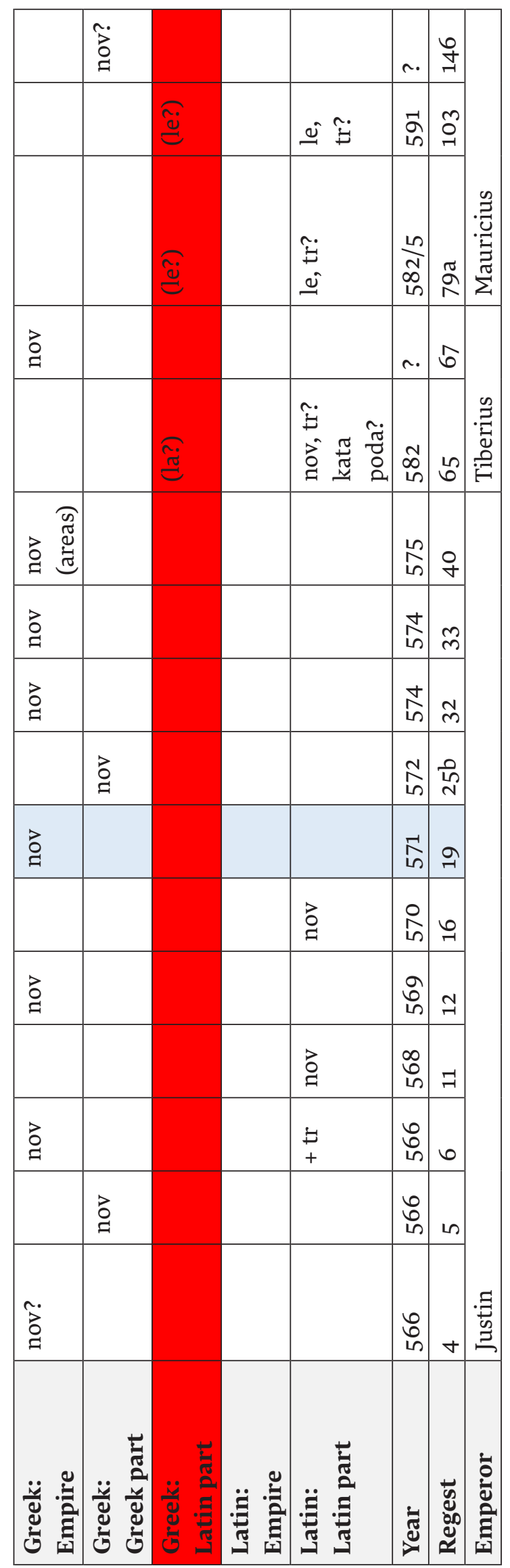




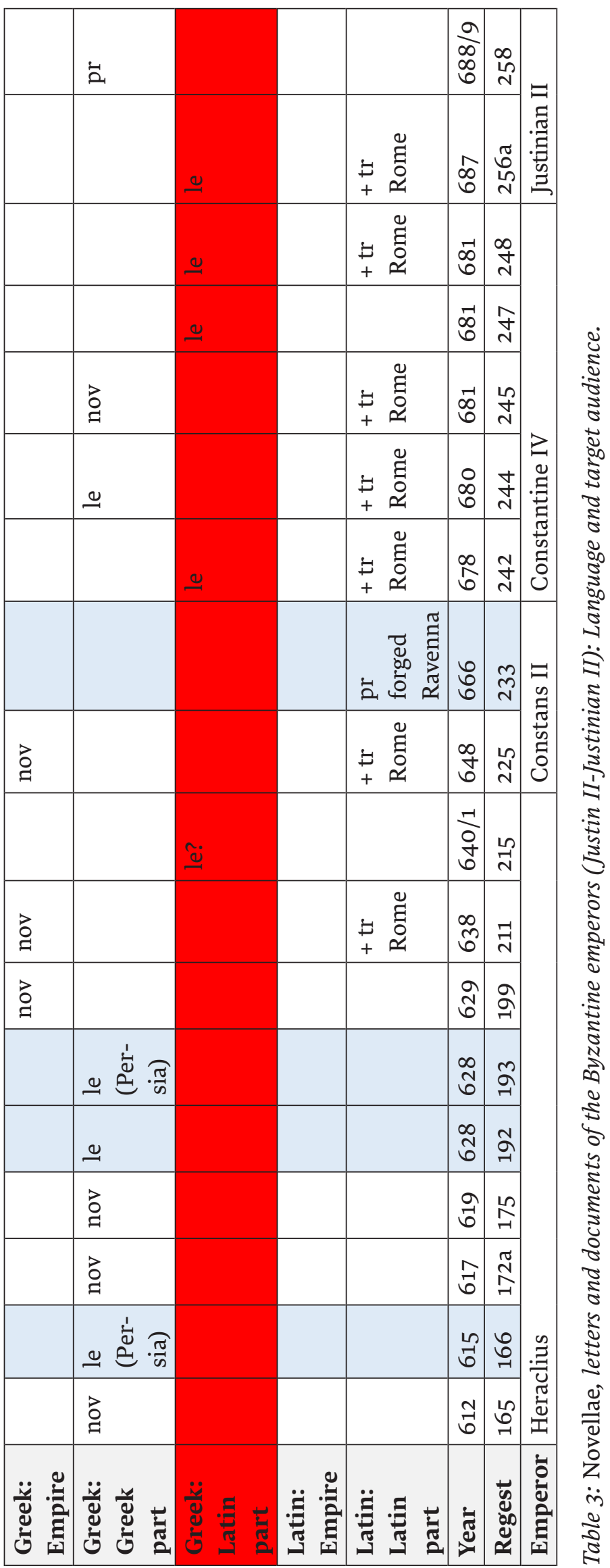




\section{Tiberius I}

At first glance, nothing seems to have changed under Tiberius I: Latin is used (regest 65) in a local matter to the praefectus praetorio Africae; the general novella regest 67 is preserved in Greek since the addressee is the senate of Constantinople which, however, does not rule out a Latin version to higher Latin officials as well.

Nevertheless, the Latin version of regest 65 raises doubts about its authenticity as the original text since some phrases rather hint at a kata poda translation; but to verify a possible verbal law school rendering, either the Greek original or the original Latin translation must be extant for comparison, as in the few cases where a Latin (inappropriate) phrase undoubtedly imitates the Greek construction as a kata poda translation, ${ }^{42}$ although, theoretically, a somehow cumbersome Latin text can also represent the original Latin version (i.e. issued in that way by the imperial chancery), inadequately rendered from a supposed Greek draft.

First doubts about a genuine Latin version arise if we compare the text with its model, the former pragmatica sanctio of Emperor Justin II, also directed to the praefectus praetorio Africae, regest 16 . One would expect that the new pragmatica sanctio refers to the vocabulary, but some technical terms differ:

(Justin II) creatos ex libera matre et adscriptitio marito liberos esse ... talem sobolem adscriptitiam esse (ZepIus 10, 11. 11-12, 13-14), filios ex libera matre et adscriptitio patre productas liberos quidem esse ... (10, 1l. 26-27) - (Tiberius I) pro conditione sobolis $a b$ adscriptitio patre et ingenua matre (ZepIus 24, ll. 14-15).

The sons of a free mother and a colonus in Justin's sanctio have become sons of an ingenua (born free) mater instead of a libera (free) mater.

(Justin II) filios, qui nascuntur ex libera matre atque adscriptitio patre, liberos esse ... sed tamen colonos (10, 11. 19-20); filios ex libera matre et adscriptitio patre productos liberos quidem (10, ll. 25-26) - (Tiberius I) liberi procreati a matre ingenua et patre adscriptitio vel colono ${ }^{43}(24,11.23-24)$

procreare (instead of nasci or producere) can also be found in a Latin novella of Emperor Justinian, dating from 7 th April 540 (preserved in appendix A to the epitome Iuliani ${ }^{44}$ ).

(Justin II) terrulas, ubi nati sunt, relinquere et alienas colere (10, 1l. 21-22); sed vicos ipsos, in quibus orti sunt, cum libertate colere (10, 1. 29-11, 1. 1), terras, ubi nati sunt, excolentes - (Tiberius I) ipsius autem cespitis, ubi nati sunt, recedere et in aliis quibuscunque locis degere $(24,11.27-28)$

42 See the meticulous analysis in Kaiser, Zweisprachigkeit, 433-467.

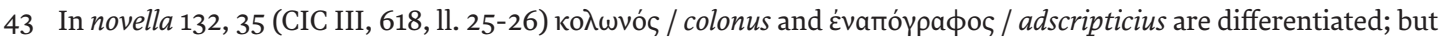
cf. the lex divina by Justinian for all Illyricianae partes in appendix A (on the appendix, see Kaiser, Epitome Iuliani, 25 ) to the Epitome Iuliani (de adscripticiis et colonis): adscripticios vel colonos commiscentes se liberis mulieribus procreare filios ad similitudinem liberorum (CIC III, 796, 1l. 4 and 7-8), de adscripticiis et colonis constitutis agricolis, quod nascitur, adscripticium et colonum fieri (CIC III, 796, 11. 10-11).

44 CIC III, 796, 11.8 and 11. 
It is strange that Tiberius' pragmatica sanction did not rely on one of the three terms defining the estate of the sons but introduced a new one that is not common in this context. Two phrases are outstandingly cumbersome:

1) pragmaticam sanctionem ... firmam illibatamque nostris etiam affatibus constitui supplicaverunt (IusZep 24, 11. 13-17). Generally, affatus means something like adlocutio or elo-

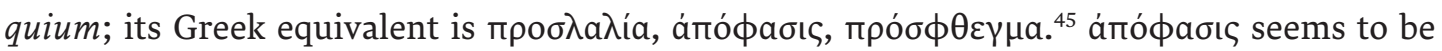
the word we are looking for, in its particular legal meaning (judgement, sentence).

The subsequent subordinate clause (ut cultura terrarum permaneat, nulla lege vel machinatione et ab ea separari valitura [24, 11. 17-19], or nulla lege vel machinatione ab ea separare valitura, as the editors propose) reflects Greek rather than Latin wording: the cultura terrarum means $ү \varepsilon \omega p$ pía or $ү \varepsilon \omega \pi$ mía; the construction with a participium coniunctum (to cultura terrarum) or absolutum (to lege and machinatione) is comparable to the kata poda

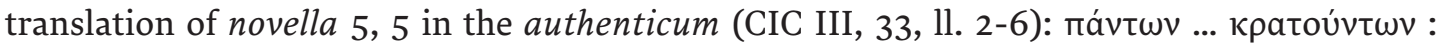
omnibus ... valituris, i.e. the Greek genetivus absolutus is translated as ablativus absolutus (the participle being valiturus ${ }^{46}$ ).

2) ... ut liberi ... rusticitatem paternam cognoscant et ... subministrent, deterioris quidem conditionis alieni, ipsius autem cespitis, ubi nati sunt, recedere et in aliis quibuscunque locis degere non permissuri (ZepIus 24, 11. 23-28)

If deterioris conditionis and cespitis are correctly transmitted, the two genetivi separati$v i$, depending on alieni and recedere, are typical Greek constructions (instead of the Latin ablativus separationi ${ }^{47}$ ); permissuri must have a passive meaning, which the Latin future

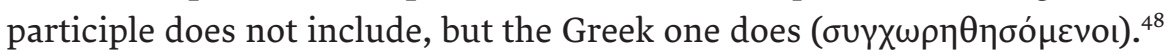

All this seems to hint at a Greek version (at best, at an inappropriate official translation of a Greek draft), which may hint at a change in issuing legal decrees even to Latin-speaking regions (here Africa). It would also explain why the wording of the former sanctio was not repeated since its text stems from the new Greek version.

\section{Mauricius}

His two Latin documents, directed to Western addressees, give the impression of following the traditional (Latin) language usage. However, these personal letters differ from legal texts insofar as they could have been sent from Constantinople in Latin or in Greek (the latter had to be translated by the addressee), but never underwent a kata poda translation in Constantinople.

Regest 79a, addressed to King Childbert II, is preserved as no. 42 in the collection of the so-called Epistolae Austrasicae (ms. Palatinus latinus 869, whose part containing the Epistolae was written in Lorsch in the first half of the ninth century). ${ }^{49}$ This collection confronts us with a further problem in linguistic research on the original version: the text of the letter suffered as a result of the inaccuracy of its scribe so that some errors (like wrong word endings indicating the cases: e.g. -es vs. -is) are due to the scribe and not to a supposed translator.

45 See Götz, Thesaurus, 39.

46 Cf., e.g., also novella 15, epilogus (CIC III, 115, ll. 12 Latin and 14 Greek).

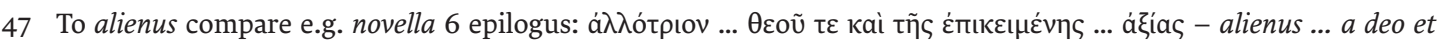

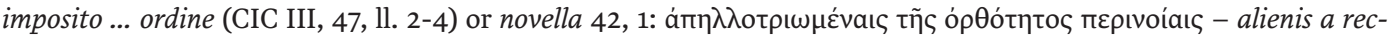
titudine sensibus (CIC III, 265, 11. 14-16)

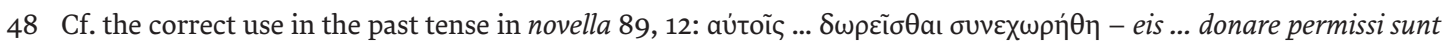
(CIC III, 440, ll. 31-32)

49 See Kautz, Bibliothek, II, 912-916. 
On the whole, the text is written in good and fluid Latin. Nevertheless, some words and phrases raise doubts about it as an original Latin version:

hoc quod et per alios ligatarios multiplicibus verbis ad nostram pietatem conscriptum invenitur (ed. Gundlach, 148, 11. 27-28); nos tamen imperialem benevolentiam sequentis (read sequentes) et praefatos ligatarios vestros suscipimus $(148,11.35-36)$. The term ligatarii (envoys) also exists in Greek, but has a different meaning: somebody who receives something by testament; it also became a particular office subordinate to the eparch of the city and is described in the Eparchikon biblion..$^{50}$ It is hard to believe that Mauricius would have made use of this term in what is supposedly an original Latin letter. On the other hand, ligatarius is found several times in other Epistulae Austrasicae, ${ }^{51}$ meaning legatus / apocrisiarius (for which, in a Greek version, we

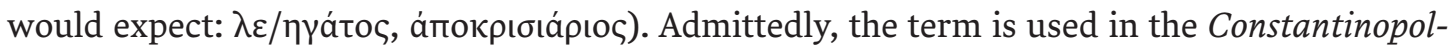
itanum III, in the list of the signing Latin council members for the papal envoys (also in Greek literally rendered as $\lambda$ пүatápıoৎ), ${ }^{52}$ but exclusively in these official documents (and even here

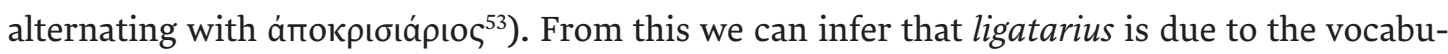
lary of a Western notary (?) rather than to the imperial chancery in Constantinople since there is not sufficient reason to suppose that a Western notary revised an original Latin version of the imperial chancery according to his vocabulary; it is more likely that a Western notary (?) translated »envoy« by a term of particular (local?) meaning and according to local custom. If so, the letter was sent in Greek and translated in the West.

dum in scriptis pollicita atque per sacerdotis (read sacerdotes) firmata et terribilibus iuramentis roborata (148, 11. 31-32): the redundant use of participles could reflect typical Greek constructions with participles (however, by articles clearly defined as substantives). The same seems to apply to enarrata $(149,1.1)$, the periphrasis his, quae nunciata ab eis sunt $(148,1.37)$ and ea, que in scriptis inter nos placita sunt $(149,11.2-3)$.

tanto tempore excesso $(148,1.32)$ is a unique phrase. In the preceding letter (41) (the exarch of Ravenna to King Chilperic) the same is expressed through transacto tempore (148, 1. 10), which is also often found in other Latin texts. tempore excesso seems to render the Greek ge-

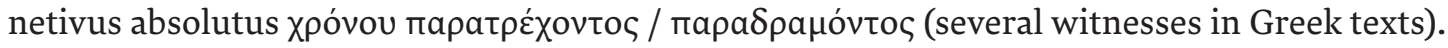

A particular case is the last line before the signature of the emperor (divinitas te servet per multos annos, parens christianissime atque amantissime, 149, 1. 8): per Manuhel (149, 1. 7). It was interpreted as a note about the imperial envoy, ${ }^{54}$ which would be exceptional at this point in an imperial letter. I assume that per Manuhel is rather a mistake by a scribe who misunderstood the introductory words (as usual in copies) to the signature of the emperor: what he read as Manuel, has to be divided in $\operatorname{manu}(m)$ and a word that includes the letters hel (or a misread combination) like imperialem.

50 Chap. 20, ed. Koder, 132-133: the legatarius is responsible for merchants coming to Constantinople.

51 See, e.g., letter 19 (King Theodebert to Emperor Justinian; ed. Gundlach, 132, 1. 25); letter 25 (King Chilperic II to Emperor Mauricius; 138, l 27); letter 26 (Queen Brunhilda to Emperor Mauricius; 139, l. 15); letter 27 (Queen Brunhilda to her son, King Athanagild; 139, 1. 33); letter 28 (King Chilperic to Athanagild; 140, 1. 14); letter 30a (Queen Brunhilda to Empress Athanasia; 141, 1. 4).

52 See ACO II, 2, 2, act. 18, ed. Riedinger, 778, 11.18 and 26; epistula Leonis II papae, 870, 1l. 3 and 28; 874, 1. 9; 884, l. 11.

53 See ACO II, 2, 1, act. 8, ed. Riedinger, 210, 1. 3; act. 4, 204, 1. 31; ACO II, 2, 2, act. 18, ed. Riedinger 780, 1l. 3 and 5 ; sermo prosphoneticus, 822, 1. 35 .

54 So also in the new revision of Regesten der Kaiserurkunden, but at least with a question mark. 
etiamsi non cognovimus et cum veritate a te transmissus (read transmissos) esse (148, 11. 36-37): cum veritate is somehow cumbersome in Latin (although witnessed in Latin texts); it

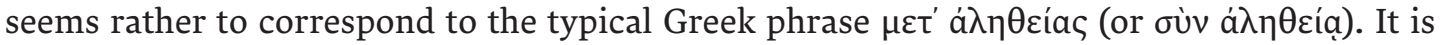
remarkable that cognovimus introduces an accusativus cum infinito and not an indirect interrogative clause. Here too, a Greek phrase (cognovimus $=\varepsilon \bar{\gamma} \gamma \omega \mu \varepsilon \nu^{55}$ with a participle relating to ligatarios vestros, here transmissos) seems to have been imitated.

To recapitulate, regest 79a could already have been issued and sent from Constantinople in the Greek language. A definite decision is impossible since the text obviously suffered during the textual transmission.

Regest 103 reacts to a letter from Bishop Severus of Aquileia and his followers to Emperor Mauricius, preserved in Latin (ed. Schwartz, 132-135), adopting some terms and phrases used by the former:

Letter from the bishops dinoscimur (133, 1. 24), dinoscitur (134, ll. 1 and 9); letter from Mauricius dinoscuntur $(136,1.8)$.

Letter from the bishops necessitatibus oppressus (133, 1. 42); letter from Mauricius necessitatem inponentes $(136,1.11)$.

Letter from the bishops suggerimus $(133,1.8 ; 135,1.3)$; letter from Mauricius suggerere $(136,1.16)$.

Letter from the bishops oportuno tempore (134, 1. 20); letter from Mauricius tempore oportuno $(136,1.16)$.

Letter from the bishops Italiae partes $(134,1.33)$; letter from Mauricius partes Italiae $(136,1.20)$.

Letter from the bishops ad pristinam libertatem reduci (134, 1. 35); letter from Mauricius ad pristinum ordinem redigantur $(136,1.21)$.

Some words may have found their way back into a Latin translation even if we suppose a Greek original, but it is more convincing that the imperial letter was composed in Latin and relied on the vocabulary of the incoming letter.

The text contains some remarkable phrases:

consuetam et deo placitam vestram sanctitatem scientes et quod rectam catholicae nostrae ecclesiae dogmatum <in > omnibus doctrinam exercetis, scire vos volumus (136, 1l. 5-6): a very intertwined sentence because consuetam et deo placitam is hard to combine with sanctitatem, it rather relates to rectam ... doctrinam. It is alluring to suppose a Greek construction (maybe only from a Greek draft), insufficiently rendered.

episcopi Histriensium provinciarum $(136,1.7)$ : the plural is unusual since it is one prov-

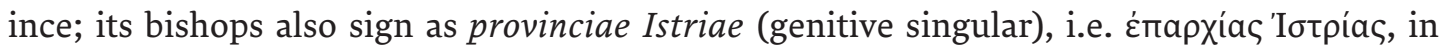
the acts of the Constantinopolitanum III (ACO II, 2, 1, ed. Riedinger, 154, l1. 9, 12-13, 15 etc.).

quousque ... et partes Italiae paceales constituantur (136, 1. 20): pacealis is a hapax legomenon; again it is tempting to suppose a Greek basis (or draft version?) like the verb

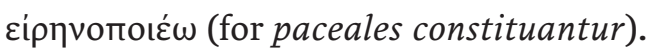

55 See, e.g., novella 40 praefatio (CIC III, 259, 1. 9). 
To sum up the two Latin letters from Mauricius, the first Latin letter of 582/585 seems to have already been sent in Greek; some phrases strongly hint at a Greek version. Some years (591) later, the emperor wrote to the pope, maybe in Latin. We would rather expect that the later letter would follow the turn to Greek; it depends on the extent to which the references to the incoming letter from the bishops are decisive to assume a Latin version. If we accept that the wording would also appear if translating from a Greek text, since some references are similar but not identical, we could suppose a Greek original for this letter as well.

\section{Heraclius}

The majority of his novellae are directed to Patriarch Sergius of Constantinople; therefore they are written only in Greek. Three letters are transmitted only in the Chronicon Paschale the authenticity of which there is reason enough to question because they are rather linguistically adapted versions (and excluded from this analysis since two of them are directed to Persian addressees).

Regest 215 (640-641), a letter in Greek to the pope, preserved in two fragments, is a very problematic text and it still needs to be examined whether and how the two fragments are really part of one letter and why the second fragment came to be preserved in the unique ms. Marcianus gr. Z 573. From a thorough consideration of the novellae of Emperor Heraclius, I am inclined to assume a Greek version only of this text since Heraclius issued his ecthesis of 638 (regest 211) only in Greek. An introductory note to the ecthesis, as preserved in the acts of the Lateran Council of 649, informs the reader that the text did exist in Greek and was translated into Latin. ${ }^{6}{ }^{6}$ Greek now really seems to have replaced Latin; the novella regest 199 (directed to Patriarch Sergius, but concerning all clergymen of the empire) also confirms this development, unless a Latin version was sent specifically to the pope.

\section{Constans II}

Like the ecthesis by Emperor Heraclius (regest 211), his typos for the entire empire was issued in Greek and continued the new language policy.

His privilege for Ravenna, regest 233, is obviously forged or at least falsified. ${ }^{57}$ Past researchers already raised doubts about the authenticity of this document, but mainly because of a serious mistake by the editors, Holder and Egger (in a footnote to their edition of the Liber pontificalis of Angellus of Ravenna): the impersonal signature of the emperor in the Codex Agnelli, written with odd letters in order to give the impression that an original document has been copied, was misread as fiat (ed. Holder and Egger, 351, 1. 42) instead of the correct legi (and so reprinted in Giorgio Orioli's discussion on the text). ${ }^{8}$ This is not the only error: the dispositive verb is also misread (and to date still not corrected) as iubemus instead of sancimus. The dispositive phrase thus reads per presentem nostram piam iussionem iubemus $(351,1.31)$ - an expression that has no parallels in other sources (as far as I was able to ascertain from consulting databases).

56 ACO II, 1, ed. Riedinger, 157, 1l. 17-18.

57 Nevertheless, it is included as authentic text in the new revision of Dölger's Regesten by Johannes Preiser-Kapeller (Dölger et al., Regesten 1, 1, 109 [regest 233]).

58 Orioli, Autocefalia, 11. Corrected in the commentary of regest 233. 
The forger was evidently familiar with imperial documents to some extent, but not in detail. I shall present here some revealing examples; a further study will explore the initial observations more thoroughly. The emperor refers to himself as (nostra) divinitas (351, 11 . 36-37) which is entirely unique in imperial documents. Admittedly, divinitas is found in imperial documents in the formulaic signature divinitas te servet per multos annos + vocative, but here divinitas relates to God, not to the emperor.

Furthermore, the core element of this text is the declaration of autocephaly of the Church of Ravenna. In the Latin text the respective term is AUTOCEPHALON (written in majuscule letters, by which the forger intends to imitate a Greek term and to corroborate the authenticity of his text as issued by a Greek emperor). However, the word is used neither in Latin texts nor in Greek ones, at least not at that time, but does reflect some knowledge of Greek on the part of a (later) forger.

Finally, the datatio at the end cannot be authentic due to the phrase imperantibus dominis nostris pissimis ... $(351,1.43)$. A comparable correct datatio can be found in the acts of the Constantinopolitanum III. ${ }^{59}$

These comments are sufficient to exclude regest 233 from a linguistic study of originals and translations. It is, however, not out of the question that there was a real privilege as the base text which was "modified « and from which some phrases were adopted.

\section{Legal Documents of the Lateran Council of 649 (Regest 211, 225)}

The ecthesis of 638 by Emperor Heraclius and the typos of 648 by Emperor Constans II are preserved as documents quoted in their entirety in the acts of the Lateran Council. Their editor, Rudolf Riedinger, corrected the traditional view of a Latin council (composed in Latin) whose Greek version was stated to be its translation. His linguistic analysis revealed that the texts were translated in precisely the opposite direction, from Greek to Latin. ${ }^{60}$ Thus, the final product had already been prepared by the Greek monks, Maximus Confessor and his followers, when they initiated the council in Rome, and the Latin translation was intended to serve the Western, Latin-speaking audience. The Greek texts are therefore the original ones, the Latin ones local translations. The acts are very strict in noting the translation of documents (they are said to have been taken from the papal archive in Rome). ${ }^{61}$

59 ACO II, 2, ed. Riedinger, 11, ll. 19-20 = regest 244 from 10th September 680: data quarto Idus Septembris Constantinopoli imperante domno piissimo perpetuo augusto Constantino imperatore anno vicesimo octavo et post consolatum eius anno duodecimo.

60 Riedinger, Aus den Akten; Riedinger, Grammatiker-Gelehrsamkeit; Riedinger, Griechische Konzilsakten 254-262; Riedinger, Sprachschichten; Riedinger, Lateransynode; Riedinger, Richtung; Riedinger, Lateranakten.

61 See (besides the passages quoted above) ACO II, 1, ed. Riedinger, 38, 1l. 4-5 = 39, ll. 4-5; 140, 11. 31-32 = 141, 1l. 3132 ( $\beta$ í $\beta \lambda$ os / codex of Dionysius Areopagites); 144, 11. 32-33 = 145, 1l. 32-33 ( $\beta$ í $\beta \lambda$ oc / codex of the heretic Themistios of Alexandria); 164, 1l. 14-15 = 165, 1l. 14-15 (acts concerning the ecthesis by Patriarch Sergius of Constantinople); 196, ll. 13-14 = 197, ll. 13-14 (letter of Patriarch Paul of Constantinople); 320, 1l. 17-18 = 321, 1l. 17-18 (quotations of the heretics Lucius of Alexandria, Apollinaris, Polemon, Severus of Antioch, Theodosius of Alexandria, Themistius of Alexandria, Coluthus, Iulianus of Halicarnassus, Theodorus of Mopsuestia, Nestorius, Paulus Persus, the Nestorian Theodulus). 


\section{Constantine IV and Justinian II}

Legal Documents of the Sixth Ecumenical Council (Constantinopolitanum III) (Regest 242, 244, $245,247,248,256 a$ )

The original language of the acts of this Ecumenical Council was Greek. The Latin version is a translation that was managed in Rome by translators who were much more skilled than their Greek compatriots about 30 years earlier for the Lateran Council, as the editor of the acts, Rudolf Riedinger, proved. ${ }^{62}$ We are informed that one of the six originals of the Greek text which was housed in the imperial palace was burnt by the monotheletic emperor Philippicus Bardanes in December $711 .{ }^{63}$ Only one other original (Greek) version was then preserved in Constantinople, in the patriarchate. ${ }^{64}$ These acts, together with the definition of faith, were signed by the emperor and the synod, and five likewise signed copies were handed over to the pope and the four Eastern patriarchs. All information stems from Agathon, ${ }^{65}$ chartophylax and protonotarius of the Patriarchate of Constantinople, who wrote the former originals and a new copy (under the new emperor Anastasius) to replace the burnt one of the imperial palace. ${ }^{66}$

Thanks to the legal documents to the West, included in the acts of the Constantinopolitanum III, we can unquestionably affirm that the development from Latin to Greek, including in letters to the Latin-speaking West, was finally completed. Against this background we likewise expect a Greek original for the divina iussio of Emperor Justinian II to the pope six years after the Sixth Ecumenical Council (regest 256a), and, indeed, the text displays a very cumbersome Latin which still reflects Greek constructions, as some examples illustrate:

dum cognitum est nobis, quia synodalia gesta eorumque difinitio (sic), quam et instituere noscitur sanctum sextum concilium, quod congregatum est in tempore sanctae memoriae nostris patris in hanc a deo conservandam regiam urbem, apud quosdam nostros iudices remanserunt (ACO II, 2, 2, ed. Riedinger, 886, 11. 12-15): the series of subordinated clauses seems to result from a paraphrasing of Greek participial constructions.

dum cognitum est ... remanserunt, haec omnino non praevidimus alterum aliquem apud se detinere ea sine nostra piissima serentitate. The references of the two demonstrative pronouns (haec, ea) remain uncertain. The second seems to relate to synodalia gesta eorumque difinitio; the first must have a proleptic sense: "we did not expect this situation (haec), i.e. that somebody else keeps them (ea) with himself without our most pious serenity.« In the Greek version the harsh construction could have been softened by an infinitive depending on an article.

62 Riedinger, Codex; Riedinger, Dokument; see also his preface in ACO II, 2, 1, IX.

63 ACO II, 2, 2, ed. Riedinger, epilogus Agathonis, 899, 1l. 25-28; epistola patriarchae Iohannis VI, 905, 1l. 18-20, see also the preface by Riedinger: ACO II, 2, 1, VII. Cf. Dölger et al., Regesten 1, 1, 141 (regest 271), without referring to the passage in the acts.

64 ACO II, 2, 2, ed. Riedinger, epistola patriarchae Iohannis VI, 905, 1l. 22-27.

65 See Lilie et al., Prosopographie 1, 41-42 (\#132).

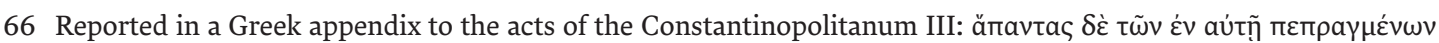
toù tó

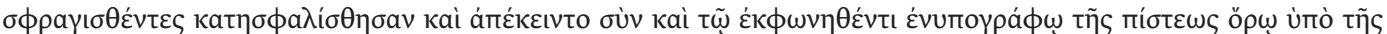

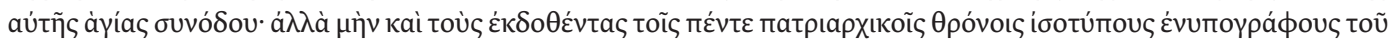

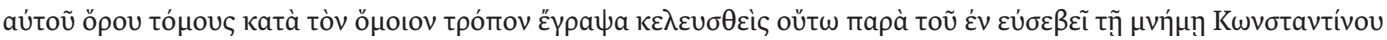

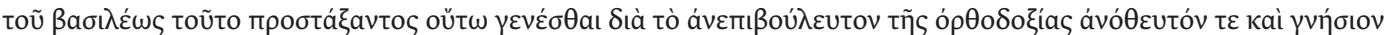
(ACO II, 2, 2, 898, 14-21). 
copiosus in misericordia noster deus $(886,1.16)$ corresponds to the Greek по $\lambda \cup \varepsilon \dot{\lambda} \varepsilon$ cos, which is rendered in the acts of the Constantinopolitanum III as misericors or misericordissimus ${ }^{67}$

exercitibus, qui inventi sunt tam ab a deo conservando imperiali obsequio $(886,1.22)$ : the phrase makes no sense unless the Greek term behind obsequio is known, i.e. ó Byzantine theme Opsikion). Another case of Greek influence is ex collegiis et popularibus

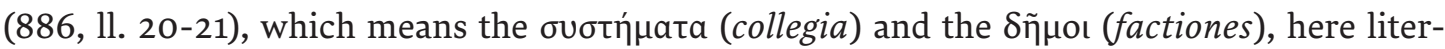
ally rendered as populares.

Et iussimus ... chartas in medio adduci et coram supradictis omnibus lectionem eorum fecisse omnesque diligenter audientes signare ipsas fecimus (997, 11. 1-2): fecisse is odd, one ms. corrects to fieri, but fecisse may reflect a Greek aorist expressing the one specific action.

ut non licentia fuerit: fuerit may again be caused by a Greek aorist, licentia seems to correspond to ä $\delta \varepsilon เ a^{68}$

usque dum noster spiritus statutus est ex deo esse in nobis $(887,1.10)$ : this cumbersome phrase obviously mirrors Greek wording.

ad sciendum itaque et vestram paternam beatitudinem huiusmodi capituli motiones praevidimus et earum scientiam notam fecisse beatitudini vestrae (887, 11. 12-13): the Latin phrase is obviously imitating a Greek construction of an infinitive depending on an article; motiones

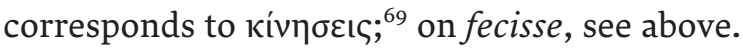

\section{Summary of the Linguistic Development until Leon III}

The products of the imperial chancery in Constantinople - and the summarising overview in tables 2 and 3 - illustrate the language turn in the capital which had its roots in Emperor Justinian's policy of bilingual or monolingual issues for the entire empire or a linguistically confined area, respectively. By studying the laws and letters of the emperors after Justinian, we are confronted with the heterogeneous transmission of the texts and the problem that the language of a preserved version does not automatically indicate the original language of the chancery; the same applies to Latin texts that are identified as translations. To base the results on firm ground, it is absolutely necessary to take the target audience and the quality of translating into account. Safe indicators of a complete turn to Greek are chancery products which are addressed to the entire empire in Greek alone and which are directed to Western addressees in Greek and omit Justinian's practice of respecting the Latin-speaking target audience. The latter are most significant for confirming the final stage of this development (in Table 3 these texts are highlighted against a red background). As discussed above, there is some evidence that this process started under Mauricius or Heraclius and it was definitely completed under Constantine IV. If our considerations are right, already under Tiberius I a pragmatica sanctio for a Latin-speaking region may have been issued in Greek (and translated by the addressee's office).

67 See ACO II, 2, 3, ed. Riedinger, 188 (the "index« is a first approach to the rich source of the acts, it is neither complete nor exhaustive. Riedinger included only some references, rather by chance).

68 See ACO II, 2, 3, ed. Riedinger, 4.

69 Cf., e.g., in the Lateran Council ACO II, 1, ed. Riedinger, 62, l. $25=63$, l. 23; or in the Constantinopolitanum III: ACO II, 2, 1, ed. Riedinger, 2, 1. $12=3$, l. 13 (negative context). 
It was without doubt a gradual development; therefore it makes no sense to query the reason for this change. We can only state that the general decrease in knowledge of Latin and the enthronisation of emperors originating from eastern, Greek-speaking regions contributed more or less to this turn. Finally, the loss of Latin-speaking parts of the empire and the presence of Greek-speaking compatriots, at least in the city of the most important addressee, the popes in Rome, some of whom were even of oriental origin, ${ }^{70}$ removed the need to respect Latin from the emperors as well.

\section{A Short Overview of the Subsequent Development of Language Usage in the Imperial Chancery}

In contrast to the domestic documents, which retained more or less traditional forms and were issued in Greek until the end of the Byzantine Empire, the Byzantine emperors notably modified the language policy of their documents to the West (i.e. of letters and privileges). This development has been analysed in some detailed studies, so I confine myself to summing up the pivotal steps.

After the Byzantine emperors endeavoured to replace Latin with Greek in the early Byzantine period, Latin was again introduced for accompanying translations (of the same documents) in order to guarantee that the text was not falsified, deliberately or incompetently, by Western translators. Such falsifications were indeed the subject of a complaint, probably by Emperor Constantine V, about the translators at the Frankish court and in Rome responsible for incorrectly rendering the imperial letters to King Pippin and Pope Paul I (765/766). ${ }^{71}$ From this one can conclude that at that time imperial letters were written only in Greek and had to be translated by the addressee. ${ }^{72}$ This fits with the development that we have demonstrated in this article.

70 See Ekonomou, Byzantine Rome.

71 Dölger et al., Regesten 1, 1, 172 (regest 325). The complaint is related in a letter from Pope Paul I to King Pippin (764/766): Itaque et hoc a Deo protecte christianitati vestrae aptum duximus intimandum: quod relectis imperalibus litteris vobisque defertis per praelatos Anthi spatarium et Sinesyum eunuchum, quas nobis ob earum seriem intuendam pro amore beati Petri fautoris vestri dirigere dignati estis, repperimus in eis adnexum, quod vestri ac nostri homines, qui ipsas imperiales syllabas, quae vobis nobisque directae sunt vel diriguntur, interpretantur, non iuxta ut ibidem exaratum est, sed aliud pro alio false interpretare (sic) audent, sed missi, qui inter partes properant, non sicut illis iniunguntur, sed acceptilationis praemio corrupti alio pro aliis deferent (Codex Carolinus, Letter 36, ed. Gundlach, 546, ll. 10-17 = Letter 20 [36], ed. Hartmann and Orth-Müller, 146; Jaffé et al., Regesta, 177 [regest 4180]). It is not entirely evident whether adnexum refers to an additional note by Emperor Constantine V or by King Pippin (to the letter[s] sent to the pope).

72 Cf. also Gastgeber, Kaiserliche Schreiben, 91-92. 
From documents to Arabic-speaking addressees (starting from the tenth century, the first indirectly preserved text dates from 839$)^{73}$ we gain first information regarding bilingual letters, the layout and material of which are also described. ${ }^{74}$ The practice of issuing documents together with a translation by the imperial chancery (at least for letters sent to non-Greekspeaking addressees) undoubtedly influenced the correspondence with the West too, ${ }^{75}$ but the "exact « date is uncertain; we can only be sure that this innovation must have been introduced before the first preserved original of $1139 .^{76}$

The reintroduction of Latin, which originals confirm only from the end of the thirties of the twelfth century (as for letters), did not mean that both languages were considered equal. ${ }^{77}$ The script (ornamental, like an inscription for Greek; simple book script and significantly smaller for Latin ${ }^{78}$ and the placement of the signature of the emperor (after the Greek text; the succeeding Latin translation is not signed) stress the difference ${ }^{79}$ between the authentic language and the Latin copy. ${ }^{80}$ Treaties - or privileges by imperial grace according to Byzantine policy - were issued in the same format.

However, at the end of the twelfth century, from which time, after a gap between 1146 and 1191, original letters and, from 1192 onwards, treaties are extant, the emphasis on the difference between Greek and Latin disappeared. The Latin translation is still written after the signed Greek text and bears no signature, but no longer differed in the shape of the script: the Greek parts are written in a very cursive script, which could surely be read only by experts from the imperial chancery; the Latin script, which was adopted from the Western chancery style, is even more calligraphic (sometimes with ornaments characteristic of contemporary Western documentary script) and aesthetical than the preceding Greek one. This was possible because Latin notaries were also engaged in the Byzantine chancery to translate Greek documents (and incoming Latin letters) and to write the Latin parts in the typical notarial ductus. Thus, the quality of the translations depended on the engagement of Latin native speakers and the skill of a Greek translator. Some Latin texts apparently reveal the struggle by translators of Greek origin and evidently reflect the low quality of translation skills in the Byzantine chancery. Nevertheless, these cumbersome and even faulty translations were the only texts that the Latin addressee read! ${ }^{81}$

73 See Kresten, Chrysographie, 157-160.

74 See Kresten, Chrysographie, 157-172; Gastgeber, Kaiserliche Schreiben, 101-102.

75 Since the so-called Kaiserbrief of St. Denis (see note 7) seems to be still written in Greek alone, the new development of letters sent abroad evidently did not start with the correspondence to the West.

76 See Gastgeber, Kaiserliche Schreiben (assuming that first Latin translations were issued in the Byzantine chancery from the tenth century on).

77 To the Byzantines, Latin was the language of the »barbarians«; see below n. 84 .

78 Cf. the figures and palaeographic commentary in Hunger, Schriftästhetik.

79 See Gastgeber, Changes.

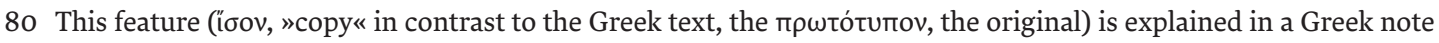
by the responsible official on the back of the privilege document for Pisa of February 1192 (Dölger and Wirth, $R e$ gesten 2, 306-308 [regest 1607]; see Otten-Froux, Enregistrement, esp. 242).

81 All documents of the twelfth century (originals and secondary transmission) are studied in Gastgeber, Lateinische "Übersetzungskanzlei«, vols. 2 and 3; cf. also the overview in Gastgeber, Übersetzungsabteilung. 
After Constantinople was conquered by the Crusaders in 1204, a gap in preserved originals means that one can only assume that the practice of the end of the twelfth century was maintained (Greek and Latin, in this order, on the same document, signature of the emperor after the Greek text). ${ }^{82}$ An innovation was introduced in two stages under Emperor Michael VIII and is connected with the emperor's confessions of faith and letters around the Second Council of Lyon (1274): first, a document was issued in Greek and Latin according to the usual practice, but now on two separate documents, both signed by the emperor; second, omitting the respective Greek version and issuing the Latin text alone. This development in practice applied only to letters; for treaties and treaty-like documents (now given new names in order to respect partners of mutual agreements on an equal level) Greek and Latin continued to be used until the end of the Byzantine Empire, but no longer in a charta transversa that started with the Greek text. Now these documents display the Greek original and its Latin translation in two parallel columns and express the parity of the two parties to the treaty through visual features as well. This final step seems to have been taken under the late Emperor Michael VIII or under his son Emperor Andronicus II at the latest. ${ }^{83}$

It is noteworthy that this innovation was a big concession by the emperor to the Latin language and the West (and has to be understood with regard to the contemporary political conditions for Emperor Michael VIII Palaiologus since Latin was a "barbarian« language to the Byzantines) ${ }^{84}$. However, it was also maintained by his son, Emperor Andronicus II, although he broke with the Latins and started an anti-Latin policy. So, the Byzantine chancery partially came back to its Latin roots because imperial letters (to Latin addressees) continued to be issued almost exclusively in Latin ${ }^{85}$ until the end of the Byzantine Empire - a language that the Palaiologan emperors had no mastery of or ability to speak. This confronts us with the question of how such letters, issued in Latin, were prepared and presented to the emperor in the final version. ${ }^{86}$

With this concluding short overview of the development after the early Byzantine turn to Greek alone, it must be emphasised that the Byzantine imperial chancery was a very dynamic institution which reacted to political changes and needs as well. The traditional image of a sluggish administrative organisation which is burdened und crushed by bureaucracy and inefficiency has to be corrected; on the contrary, the typical Byzantine feature of oikonomia, i.e. the acceptance and application of innovations due to a new state of affairs, could allow for modifications even in the very sacred sphere of the emperor's performance of issuing documents and for the deviation to the »barbarian« Latin language.

82 The documents are edited with introduction and commentary in Pieralli, Corrispondenza.

83 Cf., e.g., Gastgeber, Dossier; Gastgeber, Changes; Gastgeber, Lateinische Texte.

84 See Gastgeber, Kaiserliche Schreiben, 96-99; Gastgeber, Latin, 113-114.

85 The few exceptions demand a particular comment and will be discussed in an article that is planned for the next issue of this journal; furthermore, a new type of letter, the so-called »open letter «, was introduced from the West in the Byzantine chancery; it was shaped like a treaty and confirmed a privilege or the ownership of a gift; see Wirth, Patent.

86 This topic will be explored in greater depth in a subsequent study (see n. 85). 


\section{References}

\section{Abbreviations}

ACO I, 4, 2 = Acta Conciliorum Oecumenicorum I, 4 (Constantinopolitanum secundum)

ACO II, 1 = Acta Conciliorum Oecumenicorum II, 1 (Concilium Lateranense 649)

ACO II, 2, 1-2 = Acta Conciliorum Oecumenicorum II 2, 1-2 (Constantinopolitanum tertium)

AthSynt = Athanasios of Emesa, Syntagma

$\mathrm{CCSG}=$ Corpus Christianorum, Series Graeca

CIC III = Corpus Iuris Civilis III

Coll. CLXVIII = Corpus Iuris Civilis III, ed. Schöll and Kroll

Diktyon = ID of the Greek manuscripts provided by the database pinakes of the CNRS Paris.

Accessed on 1 March 2020: https://pinakes.irht.cnrs.fr/

HeracNov = Konidaris, Novellen

IulEpit = Iulianus, Epitome

MGH = Monumenta Germaniae Historica

TheodBrev = Theodorus scholasticus, Breviarium, ed. von Lingenthal (Greek epitome)

ZachIus III = Jus Graecoromanum III, ed von Lingenthal

ZepIus I = Jus Graecoromanum I, ed. Zepos and Zepos

\section{Primary Sources}

Acta Conciliorum Oecumenicorum, Series prima, tomus 4, volumen 2: Concilium universale Constantinopolitanum sub Iustiniano habitum, ed. Eduard Schwartz (Berlin, 1914).

Acta Conciliorum Oecumenicorum, Series secunda, volumen primum: Concilium Lateranense a. 649 celebratum, ed. Rudolf Riedinger (Berlin, 1984).

Acta Conciliorum Oecumenicorum, Series secunda, volumen secundum: Concilium universale Constantinopolitanum, 2 parts and a separate index, ed. Rudolf Riedinger (Berlin, 19901995).

Agnellus, Liber pontificalis ecclesiae Ravennatis, ed. Oswald Holder-Egger, MGH Scriptores rerum Langobardarum et Italarum saeculorum VI-IX (Hannover, 1878, reprinted 1988) 265-391.

Athanasios of Emesa, Syntagma Novellarum, ed. Dieter Simon and Spyros Troianos (Frankfurt/Main, 1989).

Chronicon Paschale, ed. Ludwig Dindorf (Bonn, 1832).

Codex Carolinus, MGH Epistolae III, Epistolae Merowingici et Karolingici aevi 1, ed. Wilhelm Gundlach (Berlin, 1892, reprinted Munich, 1994) 469-657 = ed. Florian Hartmann and Tina B. Orth-Müller, Freiherr vom Stein-Gedächtnisausgabe 49 (Darmstadt, 2017).

Corpus Iuris Civilis III: Novellae, ed. Rudolf Schöll and Wilhelm Kroll (thirteenth edition) (Hildesheim, 1993).

Epistolae Austrasicae, MGH Epistolae III, Epistolae Merowingici et Karolingici aevi 1, ed. Wilhelm Gundlach (Berlin, 1892, reprinted Munich, 1994) 110-153.

Euagrius Scholasticus, Ecclesiastica Historia, ed. Joseph Bidez and Léon Parmentier (London 1898, reprinted Amsterdam, 1964) = ed. Adelheid Hübner, Fontes Christiani 57, 2 vols. (Turnhout, 2007).

Iulianus, Epitome Latina Novellarum Iustiniani, ed. Gustav Friedrich Hänel (Leipzig, 1873). 
Jus Graecoromanum III: Novellae constitutiones, ed. Konstantin Eduard Zachariae von Lingenthal (Leipzig, 1857) = Jus Graecoromanum I: Novellae et aureae bullae imperatorum post Justinianum ex editione C. E. Zachariae a Lingenthal, ed. Ioannes Zepos and Panagiotes Zepi (Athens, 1931, reprinted Aalen, 1962).

Leon V, Eparchikon biblion (Liber praefecti), ed. Johannes Koder, Corpus Fontium Historiae Byzantinae 33 (Vienna, 1991).

Relatio motionis inter Maximum et principes, ed. Pauline Allen and Brodwen Neil, Scripta saeculi VII vitam Maximi Confessoris illustrantia, CCSG 39 (Turnhout, 1999) 12-51.

Theodorus scholasticus, Breviarium Novellarum, ed. Konstantin Eduard Zachariae von Lingenthal, Anekdota (Leipzig, 1843) 1-165.

\section{Secondary Literature}

Alexakis, Alexander, Before the Lateran Council of 649: The last days of Herakleios the emperor and monotheletism, Annuarium Historiae Conciliorum 27/28 (1995/1996) 93-102.

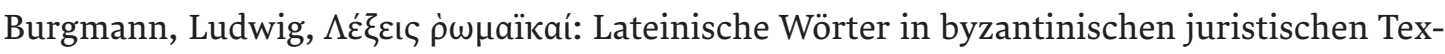
ten, in: Wolfram Hörandner and Erich Trapp (eds.), Lexicographica Byzantina. Beiträge zum Symposion zur byzantinischen Lexikographie (Wien, 1.-4.3.1989) (Vienna, 1999) 61-79.

Chitwood, Zachary, Byzantine Legal Culture and the Roman Legal Tradition, 867-1056 (Cambridge, 2017).

Dölger, Franz and Johannes Karayannopulos, Byzantinische Urkundenlehre. Erster Abschnitt: Die Kaiserurkunden (Munich, 1968).

Dölger, Franz and Peter Wirth, Regesten der Kaiserurkunden des Oströmischen Reiches. 2. Teil: Regesten von 1025-1204 (second revised edition) (Munich, 1995).

Dölger, Franz, Andreas E. Müller, Johannes Preiser-Kapeller and Alexander Riehle, Regesten der Kaiserurkunden des Oströmischen Reiches. 1. Teil, 1. Halbband: Regesten 565-867 (second revised edition) (Munich, 2009).

Feissel, Denis, Un acte de la préfecture d'Afrique sur l'église de Byzacène au début du règne de Justin II, Antiquité tardive 11 (2003) 97-112.

Ekonomou, Andrew J., Byzantine Rome and the Greek Popes: Eastern Influences on Rome and the Papacy from Gregory the Great to Zacharias, a. d. 590-752 (Plymouth, 2007).

Gastgeber, Christian, Changes in documents of the Byzantine chancery in contact with the West (Michael VIII and Andronikos II Palaiologos): Language, Material, and Address, in: Élisabeth Malamut and Nicolas Drocourt (eds.), Diplomatie byzantine (Ve-XVes.) (in print). Gastgeber, Christian, Das Dossier der documenta byzantina des 2. Konzils von Lyon (1274): Ein bislang unbekannter Rotulus aus dem Umfeld eines Konzilsteilnehmers, des Salzburger Erzbischofs Friedrich von Walchen, Jahrbuch der Österreichischen Byzantinistik 65 (2015) 13-66.

Gastgeber, Christian, Kaiserliche Schreiben des 9. Jahrhunderts in den Westen: Neue Aspekte der Übersetzungsfrage und der materiellen Ausstattung, in: Christian Gastgeber (ed.), Quellen zur byzantinischen Rechtspraxis, Aspekte der Textüberlieferung, Paläographie und Diplomatik (Vienna, 2010) 89-106.

Gastgeber, Christian, Latein in der byzantinischen Kaiserkanzlei (12.-15. Jh.), in: Christine Ratkowitsch (ed.), Medialatinitas: Ausgewählte Beiträge zum Mittellateinerkongress, Wien, 17.-21. 9. 2017 (Vienna, 2020) 105-134. 
Gastgeber, Christian, Lateinische Texte und Übersetzer der Palaiologenzeit in Konstantinopel: Der Beitrag der Kanzleien des Kaisers und des Patriarchen, in: Panagiotis Athanasopoulos and Antonio Rigo (eds.), Translation Activity in Late Byzantium (Turnhout, 2020) (in print).

Gastgeber, Christian, Die lateinische Übersetzungsabteilung der byzantinischen Kaiserkanzlei unter den Komnenen und Angeloi: Neue Ergebnisse zur Arbeit in der byzantinischen Kaiserkanzlei, in: Michel Balard, Élisabeth Malamut and Jean-Michel Spieser (eds.), Byzance et le monde extérieur: Contacts, relations, échanges (Paris, 2005) 105-122.

Gastgeber, Christian, Die lateinische »Übersetzungskanzlei« der byzantinischen Kaiserkanzlei unter den Komnenen und Angeloi. Unpublished $\mathrm{PhD}$ thesis, 3 vols. (University of Vienna, 2001).

Götz, Georg, Thesaurus Glossarum Emendatarum, vol. 1. Corpus Glossariorum Latinorum 6 (Leipzig, 1899).

Hunger, Herbert, Schriftästhetik in den drei originalen kaiserlichen Auslandsschreiben der Komnenenzeit, Römische Historische Mitteilungen 40 (1998) 187-196.

Jaffé, Philipp, Klaus Herbers, Waldemar Könighaus, Thorsten Schlauwitz, Cornelia Scherer and Marco Schütz, Regesta Pontificum Romanorum ab condita ecclesia ad annum post Christum natum MCXCVIII (third edition) (Göttingen, 2017).

Kaegi, Walter E., Heraclius: Emperor of Byzantium (Cambridge, 2003).

Kaiser, Wolfgang, Authentizität und Geltung spätantiker Kaisergesetze: Studien zu den sogenannten Sacra privilegia concilii Vizaceni, Münchener Beiträge zur Papyrusforschung und Antiken Rechtsgeschichte 96 (Munich, 2007).

Kaiser, Wolfgang, Die Epitome Iuliani: Beiträge zum römischen Recht im frühen Mittelalter und zum byzantinischen Rechtsunterricht (Frankfurt on the Main, 2004).

Kaiser, Wolfgang, Wandlungen im Verständnis der Epitome Iuliani von der Spätantike bis zur Gegenwart, in: Martin Avenarius (ed.), Hermeneutik der Quellentexte des Römischen Rechts (Baden-Baden, 2008) 300-353.

Kaiser, Wolfgang, Zu den Initia lateinischer Novellen im Breviarium novellarum des Theodorus: Studien zu den Novellen Justinians (III), Zeitschrift der Savigny-Stiftung für Rechtsgeschichte, Romanistische Abteilung 129 (2012) 501-521.

Kaiser, Wolfgang, Die Zweisprachigkeit reichsweiter Novellen unter Justinian: Studien zu den Novellen Justinians (I), Zeitschrift der Savigny-Stiftung für Rechtsgeschichte, Romanistische Abteilung 129 (2012) 392-474.

Kaiser, Wolfgang and Stylianos Chronopoulos, Unterschiede zwischen griechischen und lateinischen Ausfertigungen von Novellen am Beispiel des Gesetzes vom 15. Juni 535 über Darlehen an Bauern: Studien zu den Novellen Justinians (II), Zeitschrift der Savigny-Stiftung für Rechtsgeschichte, Romanistische Abteilung 129 (2012) 475-500.

Kaldellis, Anthony, Hellenism in Byzantium: The Transformations of Greek Identity and the Reception of the Classical Tradition (Cambridge, 2009).

Kaplan, Michel, Novelle de Tibère II sur les "maisons divines«, Travaux et Mémoires 8 (1981) 237-245.

Kautz, Michael, Bibliothek und Skriptorium des ehemaligen Klosters Lorsch I: Alba Iulia-Vat. Pal. lat. 202. II: Vat. Pal. lat. 206-Zwickau (Wiesbaden, 2016).

Kearley, Timothy G., The creation and transmission of Justinian's novels, Law Library Journal 102/3 (2010) 377-397. 
Konidaris, Ioannes, Die Novellen des Kaisers Herakleios, Fontes Minores 5 (1982) 33-106 = Konidaris, Zetemata, 85-158.

Konidaris, Ioannes, Zetemata byzantinu kai ekklesiastiku dikaiu (Athens, 1990).

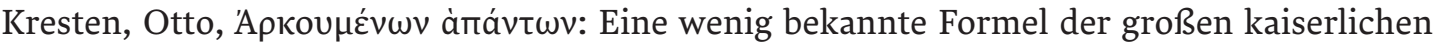
Privilegienurkunde in Byzanz, in: Ludovico Gatto and Paola Supino Martini (eds.), Studi sulle società et le culture del Medioevo per Girolamo Arnaldi, vol 1 (Florence, 2002) 277-300.

Kresten, Otto, Nachträgliches zu Dokumenten für die Kirche der Byzakene unter Kaiser Iustinos II., Byzantinische Zeitschrift 99 (2006) 495-514.

Kresten, Otto, Zur Chrysographie in den Auslandsschreiben der byzantinischen Kaiser, Römische Historische Mitteilungen 40 (1998) 139-186.

Lilie, Ralph-Johannes, Claudia Ludwig, Thomas Pratsch and Ilse Rochow, Prosopographie der mittelbyzantinischen Zeit: Erste Abteilung (641-867). 1. Band: Aaron (\#1)-Georgios (\#2182) (Berlin, 1999). Accessed on 1st March 2020: http://www.degruyter.com/pmbz.

Oikonomidès, Nicolas, Correspondence between Heraclius and Kavādh-Široe in the Paschal chronicle (628), Byzantion 41 (1971) 269-281.

Orioli, D. Giorgio, L'Autocefalia della chiesa Ravennate, Bolletino della Badia Greca di Grottaferrata n. s. 30 (1976) 3-19.

Otten-Froux, Catherine, L'enregistrement du chrysobulle de 1192 aux Pisans, Revue des Études Byzantines 42 (1984) 241-248.

Pieralli, Luca, La corrispondenza diplomatica dell'impero bizantino con le potenze estere nel tredicesimo secolo (1204-1282) Studio storico-diplomatistico ed edizione critica (Vatican, 2006).

Riedinger, Rudolf, Aus den Akten der Lateran-Synode von 649, Byzantinische Zeitschrift 69 (1976) 17-38.

Riedinger, Rudolf, Der Codex Vindobonensis 418, seine Vorlage und seine Schreiber (Steenbrugge, 1989).

Riedinger, Rudolf, Das Dokument des Petrus notarius regionarius auf seiner Reise von Rom nach Spanien im Jahre 683/4, Burgense 29 (1988) 233-250 = Riedinger, Kleine Schriften, 263-280.

Riedinger, Rudolf, Grammatiker-Gelehrsamkeit in den Akten der Lateran-Synode von 649, Jahrbuch der Österreichischen Byzantinistik 25 (1976) 57-61 = Riedinger, Kleine Schriften, 27-31.

Riedinger, Rudolf, Griechische Konzilsakten auf dem Wege ins lateinische Mittelalter, Annuarium Historiae Conciliorum 9 (1977) 253-301 = Riedinger, Kleine Schriften, 43-91.

Riedinger, Rudolf, In welcher Richtung wurden die Akten der Lateransynode von 649 übersetzt, und in welcher Schrift war der lateinische Text dieser Akten geschrieben?, in: Martino I Papa (619-653) e il suo tempo. Atti del XXVIII Convegno storico dell'Academia Tudertina e del Centro di studi sulla spiritualià medievale Todi, 1991 (Spoleto, 1992) 149-164 = Riedinger, Kleine Schriften, 283-298.

Riedinger, Rudolf, Kleine Schriften zu den Konzilsakten des 7. Jahrhunderts (Turnhout, 1998).

Riedinger, Rudolf, Die Lateranakten von 649: Ein Werk der Byzantiner um Maximos Homologetes, Byzantina 13 (1985) 517-534 = Riedinger, Kleine Schriften, 223-238.

Riedinger, Rudolf, Die Lateransynode von 649 und Maximos der Bekenner, in: Felix Heinzer and Christoph Schönborn (eds.), Maximus Confessor, Actes du symposium sur Maxime le Confesseur (Fribourg, 1982) 111-121 = Riedinger, Kleine Schriften, 169-179.

Riedinger, Rudolf, Sprachschichten in der lateinischen Übersetzung der Lateranakten von 649, Zeitschrift für Kirchengeschichte 2/3 (1981) 180-203 = Riedinger, Kleine Schriften, 137-160. 


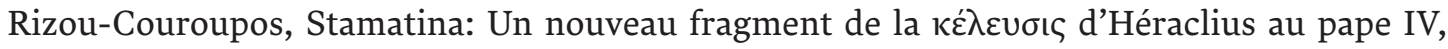
in: Jürgen Dummer (ed.), Texte und Textkritik: Eine Aufsatzsammlung (Berlin, 1987) 531532.

Simon, Dieter, Das Novellenexemplar des Athanasios, Fontes Minores 7 (1986) 117-140.

Spieser, Jean-Michel, Inventaires en vue d'un recueil des inscriptions historiques de Byzance, I: Les inscriptions de Thessalonique, Travaux et Mémoires 5 (1973) 145-18o.

Stein, Ernest, Deux questeurs de Justinien et l'empoi des langues dans ses novelles, Bulletin de la classe des lettres de l'Académie de Belgique 23 (1937) 365-390.

Stein, Ernest, Opera minora selecta (Amsterdam, 1968).

Troianos, Spyros, Die Quellen des byzantinischen Rechts, trans. Dieter Simon and Silvia Neye (Berlin, 2017).

Troianos, Spyros, Römisches Recht und byzantinisches Recht: Juristische Kuriosa bei den »Exhellenismoi«, in: Charalambos K. Papastathis (ed.), Byzantine Law: Proceedings of the International Symposium of Jurists, Thessaloniki, 10-13 December 1998 (Thessalonica, 2001) 15-20.

Wirth, Peter, Das Patent - Ein unerkannter Typus der byzantinischen Kaiserurkunde, in: Ernst v. Caemmerer, Joseph Heinrich Kaiser, Gerhard Kegel, Wolfram Müller-Freienfels and Hans Julius Wolff (eds.), Xenion: Festschrift für Pan. J. Zepos 1 (Athens, 1973) 735-738.

\section{List of Figures}

Table 1: Document overview.

Table 2: Novellae, letters and documents of the Byzantine emperors (Justin II-Justinian II): Language.

Table 3: Novellae, letters and documents of the Byzantine Emperors (Justin II-Justinian II): Language and target audience. 